OECD Local Economic and Employment Development (LEED) Papers 2016/02

\title{
Boosting Job Creation in Kalmar, Sweden
}

\section{Lars Niklasson,}

Jonathan Barr,

\section{Michela Meghnagi}

https://dx.doi.org/10.1787/5jlzbdjgx8s1-en 

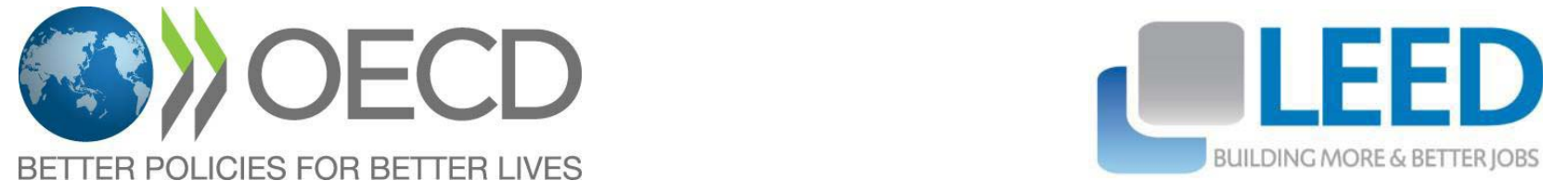

\section{Boosting Job Creation in Kalmar, Sweden}


OECD Working Papers should not be reported as representing the official views of the OECD or of its member countries. The opinions expressed and arguments employed are those of the authors.

Working Papers describe preliminary results or research in progress by the author(s) and are published to stimulate discussion on a broad range of issues on which the OECD works. Comments on Working Papers are welcomed, and may be sent to the Centre for Entrepreneurship, SMEs, Tourism and the Local Economic Development, OECD, 2 rue André-Pascal, 75775 Paris Cedex 16, France.

Authorised for publication by Stefan Kapferer, Director, Centre for Entrepreneurship, SMEs, Tourism and Local Development

You can copy, download or print OECD content for your own use, and you can include excerpts from OECD publications, databases and multimedia products in your own documents, presentations, blogs, websites and teaching materials, provided that suitable acknowledgment of the source and copyright owner is given. All requests for public or commercial use and translation rights should be submitted to rights@oecd.org. Requests for permission to photocopy portions of this material for public or commercial use shall be addressed directly to the Copyright Clearance Center (CCC) at info@copyright.com or the Centre français d'exploitation du droit de copie (CFC) at contact@cfcopies.com. 


\section{ACKNOWLEDGEMENTS}

This review has been written by the Local Economic and Employment Development (LEED) Programme of the Organisation for Economic Co-operation and Development (OECD) as part of a project undertaken in co-operation with the Regional Council in Kalmar county (Regionförbundet i Kalmar län).This project is part of the OECD LEED programme of work under the leadership of Sylvain Giguère.

The principal authors are Lars Niklasson (Linköping University), Jonathan Barr, and Michela Meghnagi (OECD). The authors would like to thank François Iglesias, Pierre Georgin, Angela Attrey and other colleagues in the OECD LEED Programme for their assistance with the preparation of this report.

Finally, special thanks are given to the local representatives who participated in the project interviews and roundtables, and provided documentation and comments critical to the production of the report. 


\section{TABLE OF CONTENTS}

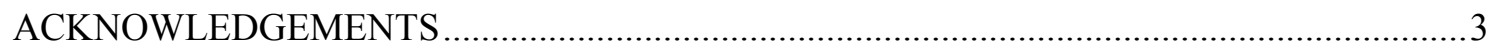

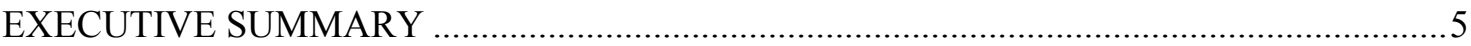

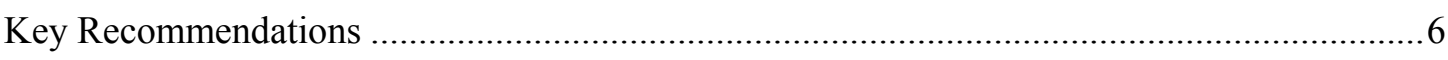

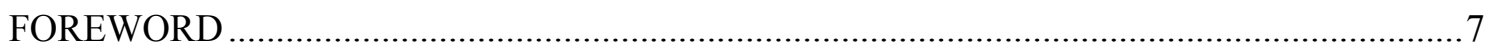

LABOUR MARKET AND ECONOMIC CHARACTERISTICS OF KALMAR COUNTY ....10

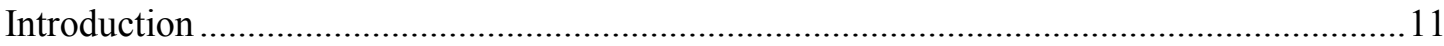

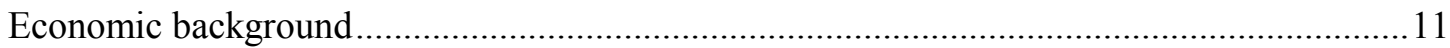

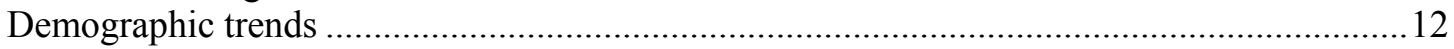

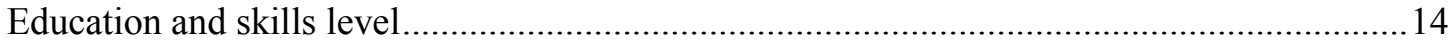

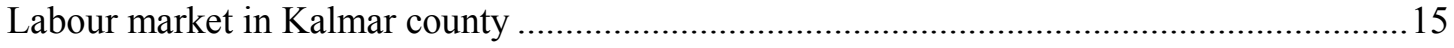

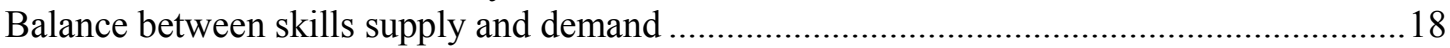

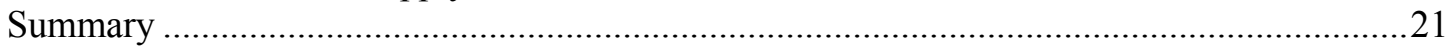

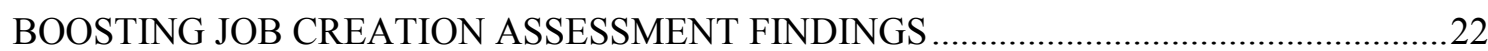

Co-ordination between employment, skills and economic development policies....................24

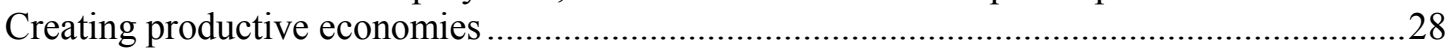

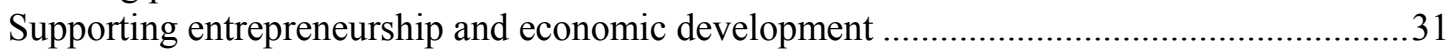

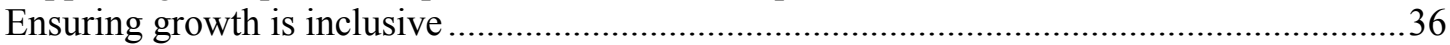

TOWARDS AN ACTION PLAN FOR KALMAR: RECOMMENDATIONS

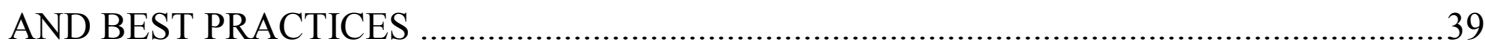

\section{Boxes}

Box 1. Summary of the OECD LEED Boosting Job Creation Methodology ............................

Box 2. Boosting Job Creation: Assessment Tool .................................................................

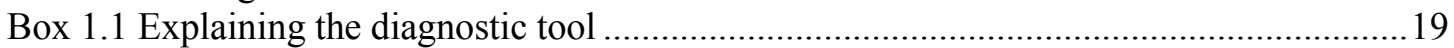

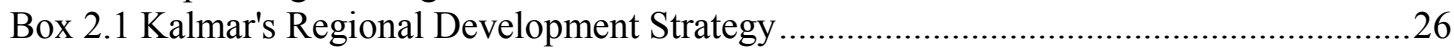

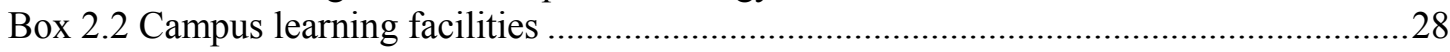

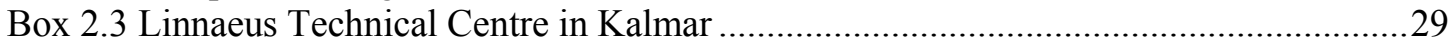

Box 2.4 A local economic development strategy for the food sector.......................................30

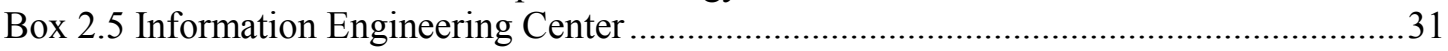

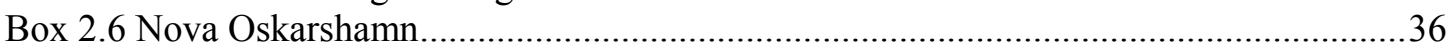

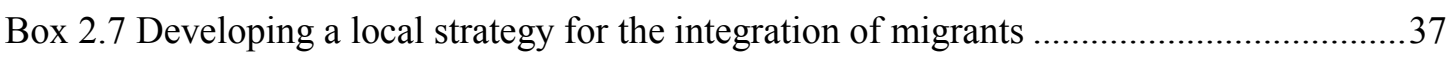

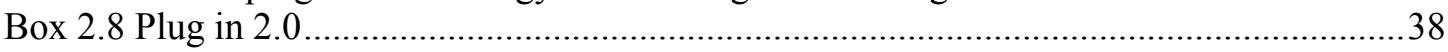

Box 3.1 OECD example: How to build successful partnerships? ...........................................4

Box 3.2 OECD example: Mechanisms which can boost the utilisation of skills .....................42

Box 3.3 OECD Example: Career cluster approaches in Maryland, United States .....................43

Box 3.3 OECD Example: Creating a new type of tourism in Blackpool, UK .........................44 


\section{EXECUTIVE SUMMARY}

By most international OECD comparisons, Sweden is a country with a high standard of living, quality of life, and a robust system of active labour market programmes and policies. Sweden is also one of the most innovative OECD economies. Looking at the regional level, Kalmar county is a region that is blessed with natural assets in terms of forest, water and geography. However, it is an area that has also been vulnerable to external fluctuations in the global economy. While the county experienced fairly robust growth before the global financial crisis and a strong rebound afterwards, it has struggled to regain its potential since 2010 .

The OECD Local Economic and Employment Development (LEED) programme has developed a policy innovation project on Boosting Job Creation with the objective of helping local economies develop evidence-based approaches to job creation that are based on broad consensus from local stakeholders. In Kalmar, the project has built on research and analysis into workforce and skills development issues in the county. The project has also extensively engaged a number of local stakeholders in Kalmar to gather additional intelligence and information about the key policy challenges facing the county and what actions are necessary going forward to stimulate growth and prosperity. A previous OECD territorial review of the Småland-Blekinge area was completed in 2012 and many of significant issues highlighted in that report remain prevalent, especially within Kalmar county.

Demographic changes will exert significant pressures on the local economy in Kalmar county. From 2003-2012, the county experienced a net decline in population as people moved away from the region to look for job opportunities in other parts of Sweden. Furthermore, Kalmar county is in a low-skills equilibrium where a low demand for skills is met with a low supply of skills. This suggests that there is a prevalence of low quality jobs in the region, where employers have limited incentives to upskill their workforce, further negatively impacting economic development opportunity.

Local employment and economic development efforts in Kalmar county must focus on how to boost productivity and move economic activity into value-added production and sectors. This means looking at how to efficiently co-ordinate public policies and working with local employers to upskill the existing workforce through targeted policies and programmes. While some efforts have been introduced in the agriculture sector, they could be expanded to tourism and retail, which are also prominent in the region. In terms of employment and training, more efforts need to be made to work with local primary and secondary schools to create career pathways or clusters that can provide information to students about future job opportunities available and how to best pursue training that is linked to local industries.

Interestingly, there is evidence that women in the county face a bipolar labour market with a mix of high and low skilled jobs. Targeted programmes and policies should be introduced to promote women's participation, particularly for those who are low-skilled. Lastly, immigrants represent a critical source of labour supply for Kalmar county to boost the supply of skills in the region. It will be critical to ensure that there is a full suite of integrated services to provide immigrants with adequate foreign credential recognition, language training, and labour market advice on how to integrate into the local community. 


\section{Key Recommendations}

\section{Co-ordination between employment, skills, and economic development policies}

- Transform regional partnerships into systems of learning that effectively promote evidencebased approaches to job creation, employment, and participation

\section{Creating productive economies - avoiding the low skills trap}

- Place a stronger emphasis on the quality of jobs and the better utilisation of skills to stimulate overall productivity within the local labour market

- Increase the engagement of employers (especially SMEs) with the employment and skills system through greater outreach efforts and examine how to apply "career pathway" approaches in the region

\section{Supporting entrepreneurship and economic development}

- Improve job quality in targeted sectors, such as tourism, by shifting from medium and low technology industry to more knowledge- intensive production

\section{Ensuring growth is inclusive}

- Increase the labour market participation rate, especially among vulnerable groups, such as immigrants and women. This could be done through strong entrepreneurship opportunities which provide skills and mentorship opportunities. 


\section{FOREWORD}

The Local Economic and Employment Development Programme at the OECD is engaging with local economies to help them prepare evidence-based approaches to job creation that are based on a as broad as possible consensus from local stakeholders. The OECD brings over three decades of experience in this area to the task, having analysed and accumulated lessons from successful approaches to local job creation worldwide. Localities are helped to identify the elements that need strengthening in their existing strategies. Realistic proposals for change are considered, bearing in mind national and local policy contexts. This work is underpinned by concrete examples of methods used in places facing similar challenges, both within each country and elsewhere.

The key stages of each review are summarised in Box 1.

\section{Box 1. Summary of the OECD LEED Boosting Job Creation Methodology}

- A gap assessment: this will involve establishing strengths and weaknesses of the local labour market, and the local policy context using key indicators and benchmarks established by the OECD.

- A workshop to discuss its results and their implications for local actions: in this roundtable local stakeholders will be helped to identify key opportunities and key challenges associated with the local context for local job creation, building on the gap assessment. The OECD will bring evidence and best practices emerging from the experience of other areas facing similar challenges.

- An action plan and practical suggestions for its implementation: building on the discussions at the workshop, an action plan will be developed in consultation with all stakeholders involved. This will set out key objectives and practical steps to undertake in relation with the obstacles identified during the discussions. Mechanisms for ongoing support from the OECD will also be identified where necessary and/or appropriate.

High unemployment remains a pressing concern for many localities and regions following the economic crisis. In many places it will take time before employment and productivity fully recovers. This is obviously a concern for national governments. But national policies do not dictate a community's future. Municipalities, districts, provinces and regions have it within their power to speed up change and seize new economic opportunities. With the right strategies and implementation plans, the fortunes of local businesses, jobs and people can be significantly changed for the better.

Engineering successful strategies for job creation is not an easy task, and requires putting many different parts of the 'policy jigsaw' into place. Local and regional authorities must have the capacity to act quickly and decisively on the strengths and weaknesses of their local economy, building on local comparative advantage, while remaining open to diversification and change. And they must show a commitment to engaging all local stakeholders in order to build the critical capacities and resources required to generate real and long-term growth. 
In response to this issue, the OECD LEED Programme has developed a set of thematic areas on which local stakeholders and employment and training agencies can focus to build sustainable growth at the local level. These include:

1. Co-ordination between employment, skills, and economic development policies: As we move towards a knowledge-based economy, a skilled workforce is becoming increasingly important to firms' decisions to locate and/or expand in a local area. This makes it essential to align labour market, training and economic development policy locally. Businesses need to be able to source appropriate skills as they expand and grow.

2. Creating productive economies - avoiding the low skills trap: There is considerable local variation in employer demand for skills. Some areas are stuck in a "low skills equilibrium", where local employers offer low-skilled jobs and operate in low-cost markets, so there are few high quality jobs available. In such regions, technical assistance, management training, and embedding skills policies in broader mechanisms for business support can encourage demand for higher levels of skills.

3. Supporting entrepreneurship and economic development: Net job creation is typically led by a small number of "high growth firms" which are strongly dependent on their local economic context. Policy makers can support such high growth by developing local entrepreneurial ecosystems and targeted support such as business accelerators. Partnerships between universities, vocational training institutions, local economic agencies and firms can help to promote knowledge-sharing and hence innovation and diversification - building new jobs on the back of old ones.

4. Ensuring growth is inclusive: Some disadvantaged groups, such as young people not in education, employment, or training (NEET), can face multifaceted barriers to employment, requiring targeted support to ensure that no individuals or communities are left behind. Using evidence-based approaches is critical to addressing both the immediate barriers to employment and the root causes of long-term labour market exclusion.

\section{OECD Gap Assessment}

As part of the project, the LEED Programme has drawn on its previous research to develop a set of best practice priorities in each area, which is used to assess local practice through a gap assessment tool (see Box 2). The dashboard enables local policy-makers to gain a stronger overview of the strengths and weaknesses of the current policy framework, whilst better prioritising future actions and resources. A value between 1 (low) to 5 (high) is assigned to each indicator corresponding to the relative strengths and weaknesses of local policy approaches based on best practices in other OECD countries.

\section{Box 2. Boosting Job Creation: Assessment Tool}

1. Co-ordination between employment, skills and economic development policies -- Better aligning policies and programmes to local economic development

1.1. Degree of flexibility in designing and implementing policies and initiatives

1.2. Degree of integration between employment, skills and economic development

1.3. Degree of utilisation of local data in evidence-based policy making

2. Creating productive economies -- Adding value through skills and avoiding the low skills trap 
2.1. Extent to which training is available in a broad range of sectors, flexible and accommodating the needs of workers and unemployed individuals

2.2. Degree of employer engagement in orienting skills development to demand and extent to which training meets business needs

2.3. Degree of support to employers/SMEs in maximising skills utilization, improving work organisation, human resource management, workforce planning and skills development

3. Supporting entrepreneurship and economic development -- Targeting policy to local employment sectors and investing in quality jobs

3.1. Extent to which programmes and services are adapted to local business demographics and profiles, addressing SME needs

3.2. Degree of access to finance by SMEs

3.3. Extent to which SMEs are helped to benefit from internationalisation opportunities

3.4. Degree of development of local entrepreneurial/innovation ecosystems, and extent of knowledge-sharing

4. Ensure growth is inclusive - seizing economic and skills development opportunities to strengthen the vulnerable in the labour market

4.1. Extent to which effective policies are in place to support the labour market integration of disadvantaged groups and degree of flexibility in adapting programmes to different target groups

4.2. Extent to which there are evidence-based tools used to measure disadvantage on the labour market and support multi-stakeholder approaches to tackling disadvantage

\section{The approach for Kalmar}

This study has looked at the range of institutions and bodies involved in workforce and skills development in Kalmar län (Kalmar county), Sweden. It should be noted that this report does not look specifically at local activities on the island of Öland, which, though a part of Kalmar county, has its own distinct identity. However, the data presented in this report on labour market and employment trends includes Öland. In early June 2015, interviews were conducted with a broad set of stakeholders from the employment, training, and economic development sectors. The purpose of the interview was to map the local institutional framework as well as to identify current local practices to boost job creation. Preliminary findings were presented and discussed at a workshop in Kalmar in September 2015 and at a major conference on regional economic development in Oskarshamn in October 2015. 


\section{Section 1}

\section{LABOUR MARKET AND ECONOMIC CHARACTERISTICS OF KALMAR COUNTY}

Kalmar county is a predominantly rural county in the southeast of Sweden. Trends show that the population has decreased and become older in recent years. However, thanks to the positive immigration flows, long-term challenges related to labour market shortages are partially reduced.

The local labour market was strongly affected by the economic downturn but unemployment has fallen over the last two years and compared favourably with the rest of Sweden in 2014. However, the county's labour productivity is one of the lowest in the country. The local economy is characterised by strong public and manufacturing sectors.

When comparing the supply and demand of skills, Kalmar is in a low skills equilibrium but very close to a skills deficit. This indicates that although both the supply and demand of skills should be improved to move towards a high skills equilibrium, raising the level of skills supply and retain skilled workers should be a key priority for policy intervention. 


\section{Introduction}

Kalmar län, named after the city of Kalmar, is a county in the southeast of Sweden; it was an important trading port and administrative centre in medieval times. It is located in the middle of Scandinavia and gave name to the union of three kingdoms, Denmark, Norway and Sweden (including Finland), the so-called Union of Kalmar.

Kalmar is considered a predominantly rural remote area because of its low population density of 21 persons per square kilometre. The county has twelve municipalities and a total population of 236000 persons. The most populated city is Kalmar with approximately 36000 inhabitants (Statistics Sweden, 2015). The city of Kalmar is also the administrative capital of the region, with a number of industries and a Linneus University campus.

\section{Economic background}

The Swedish economy has proved resilient throughout the global financial and economic crisis and its output is now above the pre-crisis level (OECD 2015a). However, like in many other OECD countries, productivity growth has slowed in latest years. With a GDP of 72600 million SEK in 2013, Kalmar county contributes to only $1.9 \%$ of Sweden's total production. This places Kalmar among the five counties with the lowest GDP contribution to national growth. In addition to the recent economic crisis, this trend can be partly attributed to the difficult accessibility and limited transport infrastructure of Kalmar county and more broadly of the Småland-Blekinge area (OECD, 2012).

Figure 1.1 shows that if the county recovered relatively quickly from the 2008 crisis, its GDP has been growing at a much slower pace than the rest of the country. Within Sweden, Kalmar has among the lowest average levels of GDP per capita and GDP per employed (Figure 1.2), which indicates a low level of labour productivity in the county. GDP per employed grew on average by $2.2 \%$ annually in Kalmar between 2003 and 2013, whilst the Swedish average level grew by $2.8 \%$ and by $3.4 \%$ in Stockholm county.

Figure 1.1 GDP (million SEK), Kalmar county, 2003-2014

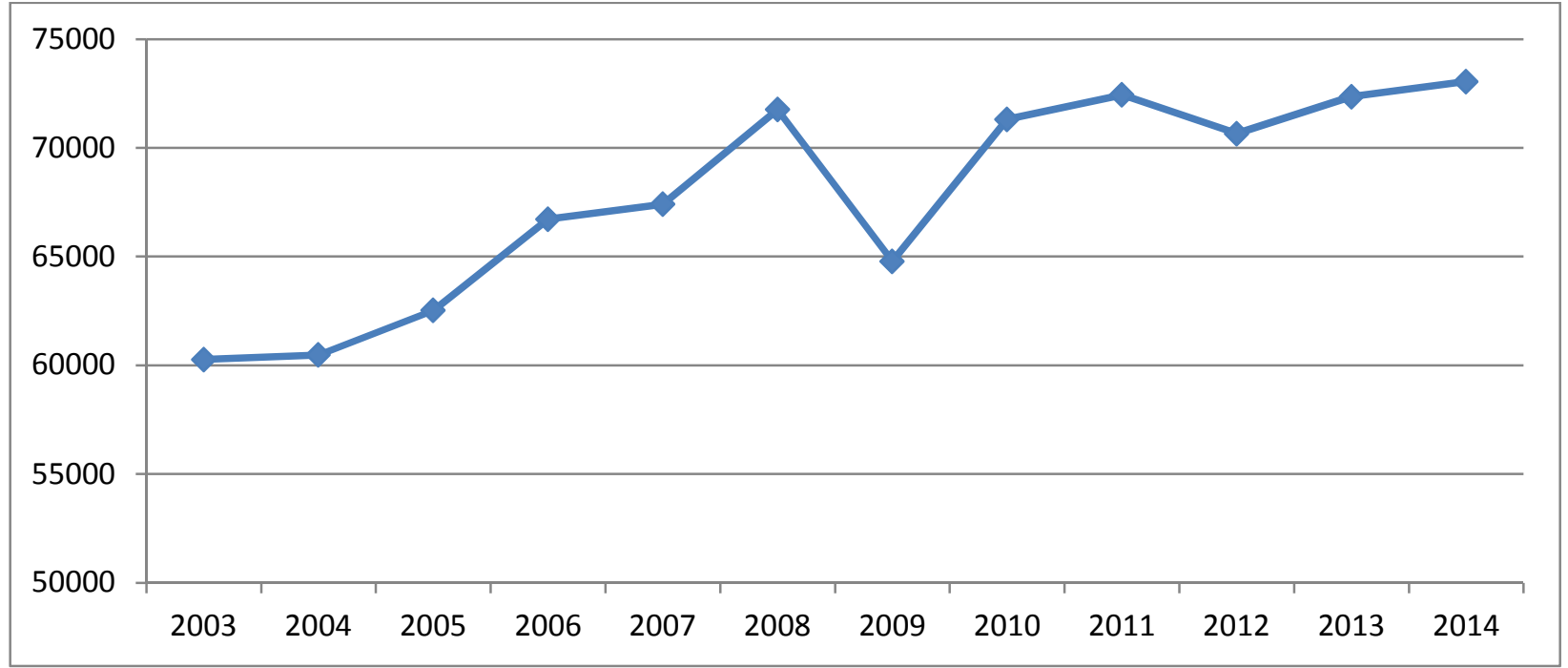

Source: Statistics Sweden 
Figure 1.2 GDP per capita and per employed (thousand SEK), sub-regions (TL3), Sweden, 2014

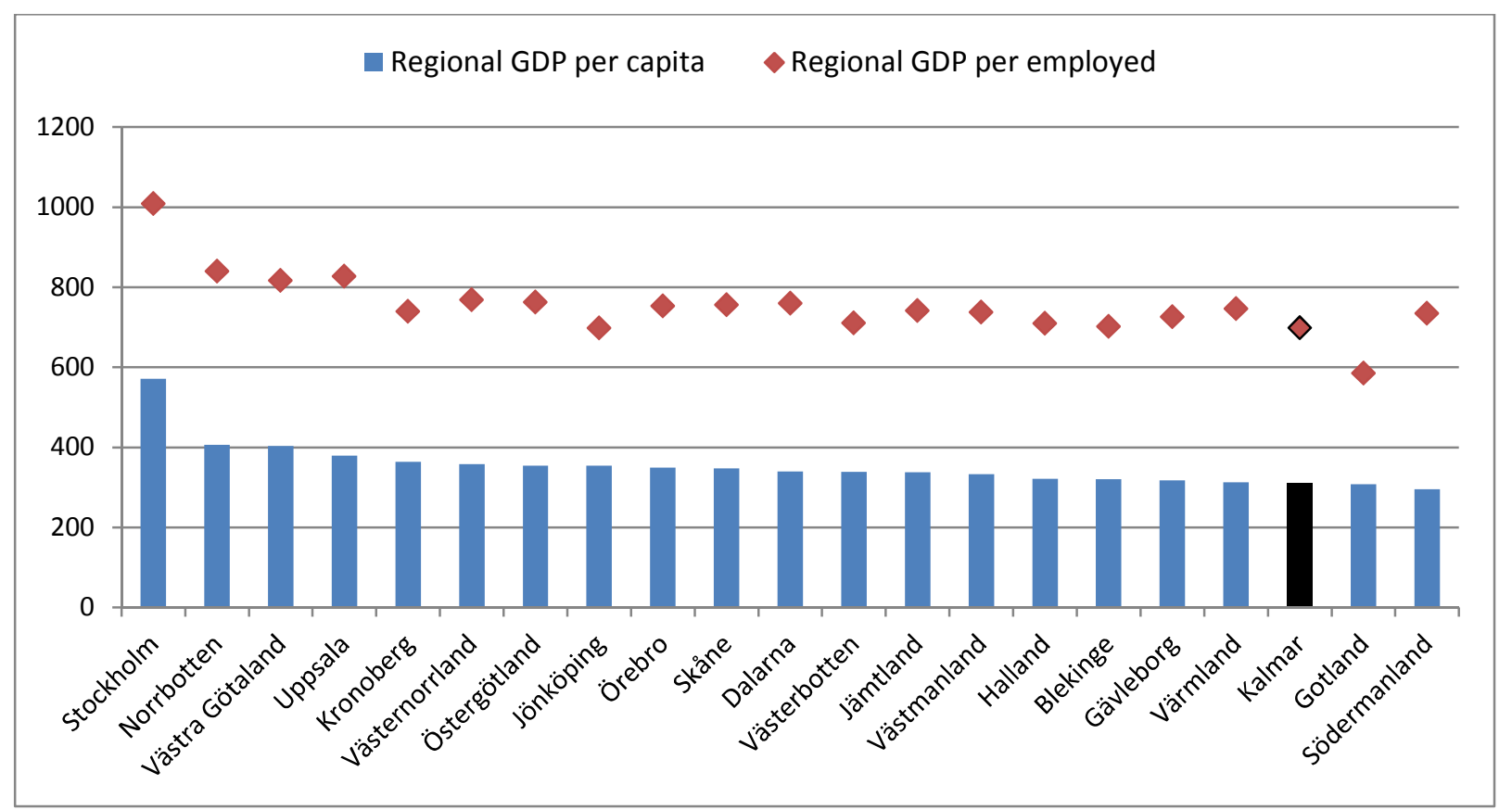

Source: Statistics Sweden

\section{Demographic trends}

In recent years, the population of Kalmar county has registered a slow decrease. Between 2000 and 2015, Kalmar saw a net decline of 7500 inhabitants due to the negative migration flows from the county towards other parts of Sweden (Figure 1.3).

Figure 1.3 Internal migration in Kalmar county (persons), 2000-2015

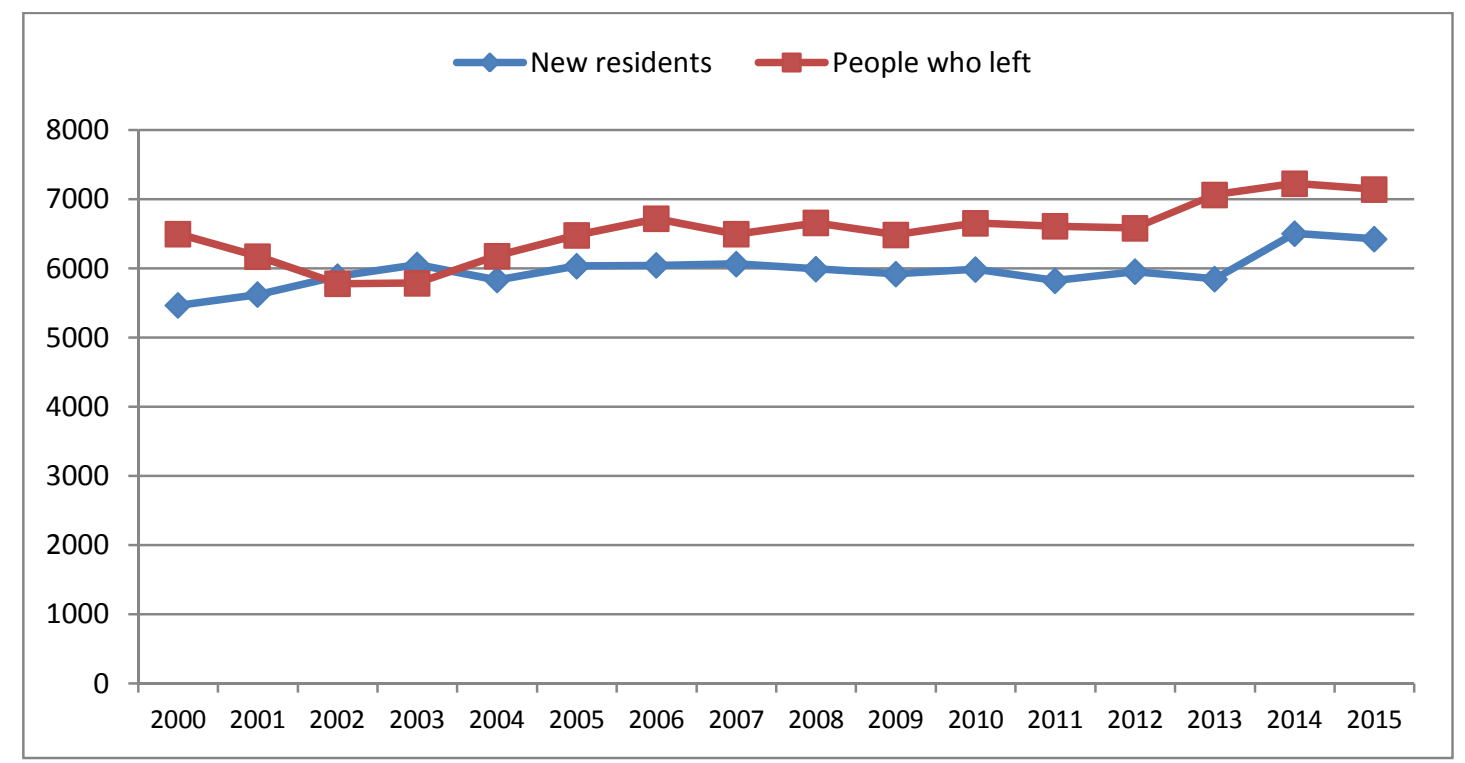

Source: Statistics Sweden 
The overall population of Kalmar county is older than in the rest of Sweden, which may impact the available supply of labour and skills. More precisely, the working age population (aged 15-65 years) in Kalmar is $59.9 \%$ of total population which is almost 3 percentage points lower than the Swedish average. The available youth population is notably lower than the Swedish average while the proportion of elderly people is higher (see Figure 1.4).

Figure 1.4 Distribution of population in Kalmar county and Sweden by age, 2015

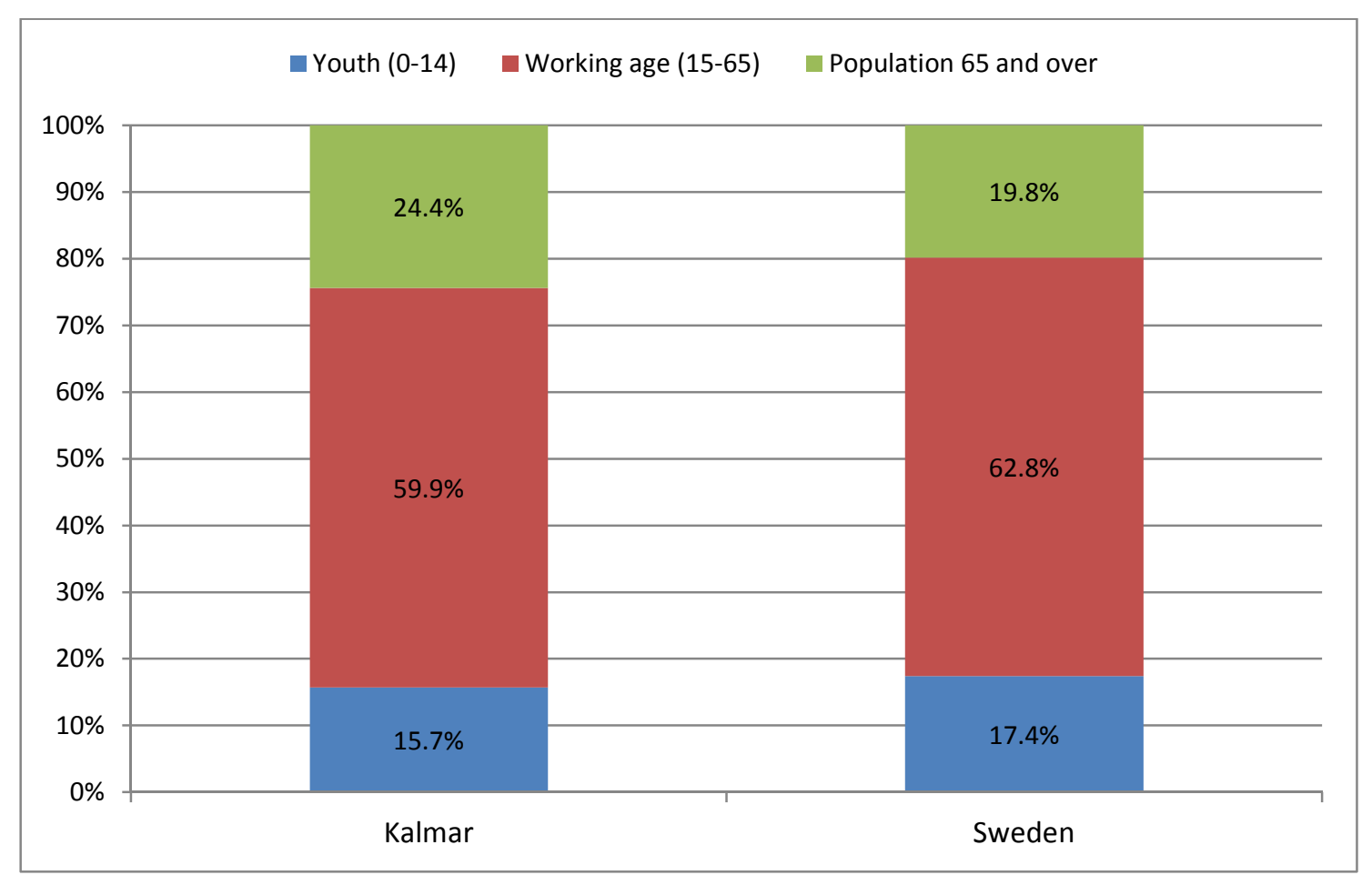

Source: Statistics Sweden

Between 2001 and 2015, the share of foreign born has increased both in Kalmar and in Sweden (see Figure 1.5). This trend will certainly accelerate in the next years due to the inflow of refugees to Sweden. Given that immigrants, both men and women, are generally younger than the Swedish born population ( $74 \%$ of female and $75 \%$ of male immigrants were of working age population in 2014), such immigration flows can counterbalance the downward pressures of an ageing population and reduce labour market shortages over the long term. Similar to many other regions within the OECD, the labour market integration of immigrants and their contribution to growth will depend on the capacity of policies and programmes at the local level to match labour needs with migrants' skills and characteristics (OECD, 2014). 
Figure 1.5 Share of foreign born in Kalmar county and in Sweden, 2001-2015

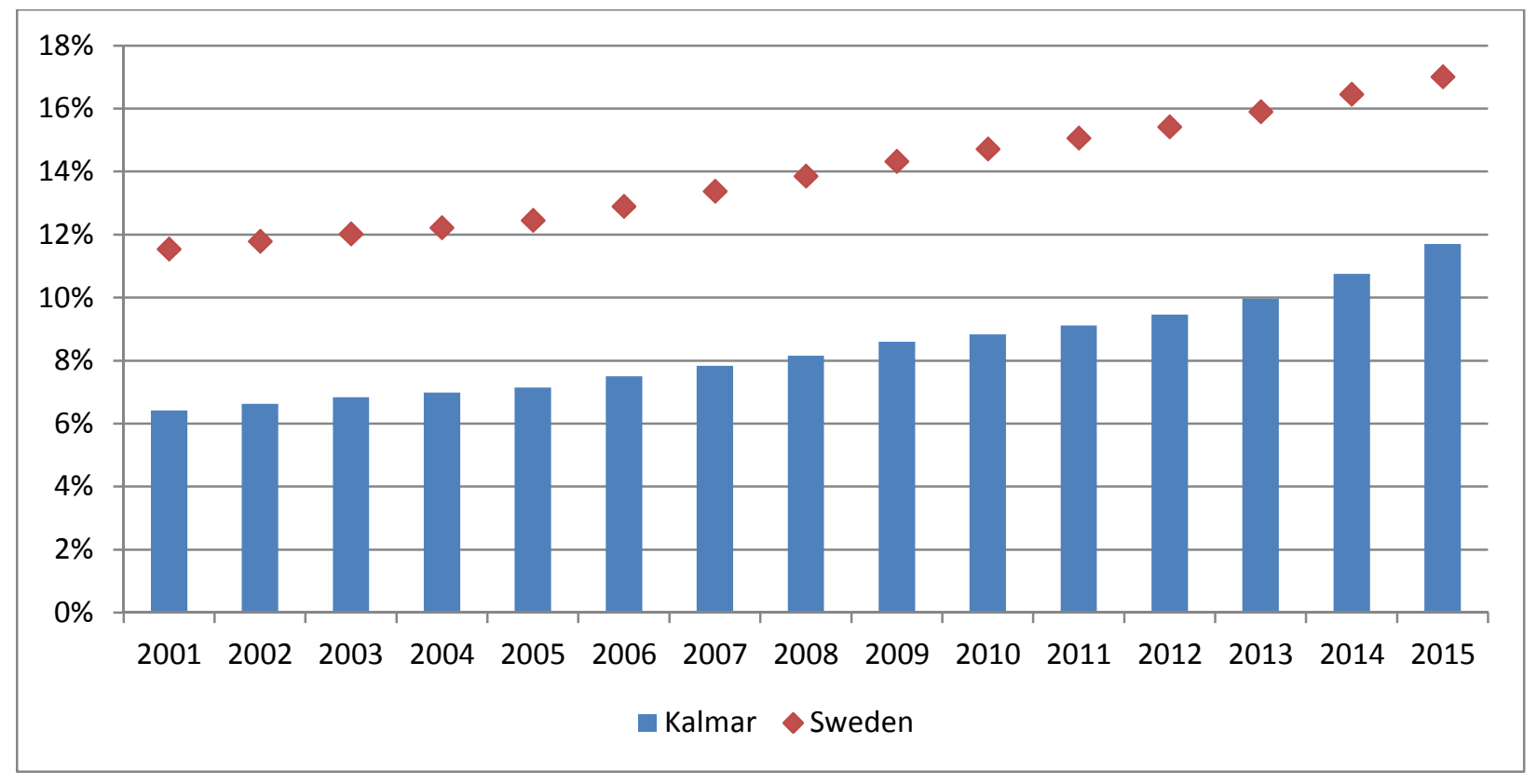

Source: Statistics Sweden

\section{Education and skills level}

Sweden has a relatively high level of both educational attainment and skills, as measured in the OECD Survey of Adult Skills (PIAAC) (Bussi and Pareliussen, 2015). However, recent results from the OECD PISA survey show that the scores of 15-year olds have decreased (OECD, 2015a). Some of the factors that contribute to these recent poor educational outcomes include deficiencies in the training of teachers, lack of support for students experiencing difficulty and the unattractiveness of the teaching profession.

The level of education of the population in Kalmar can be considered relatively low in comparison to the rest of Sweden. Kalmar ranks 18th out of 21 Swedish counties for both its share of individuals with low educational attainment $(17 \%$ of individuals have 10 years or less of education compared to the Swedish average of $15 \%)$ and its share of individuals with tertiary education $(22.1 \%$ compared to the Swedish average of 24.2\%). This is in spite of the presence of a university with over 9000 students in Kalmar. 
Figure 1.6 Share of population with post-secondary education and primary \& secondary education (10 years or less), Swedish counties, 2014

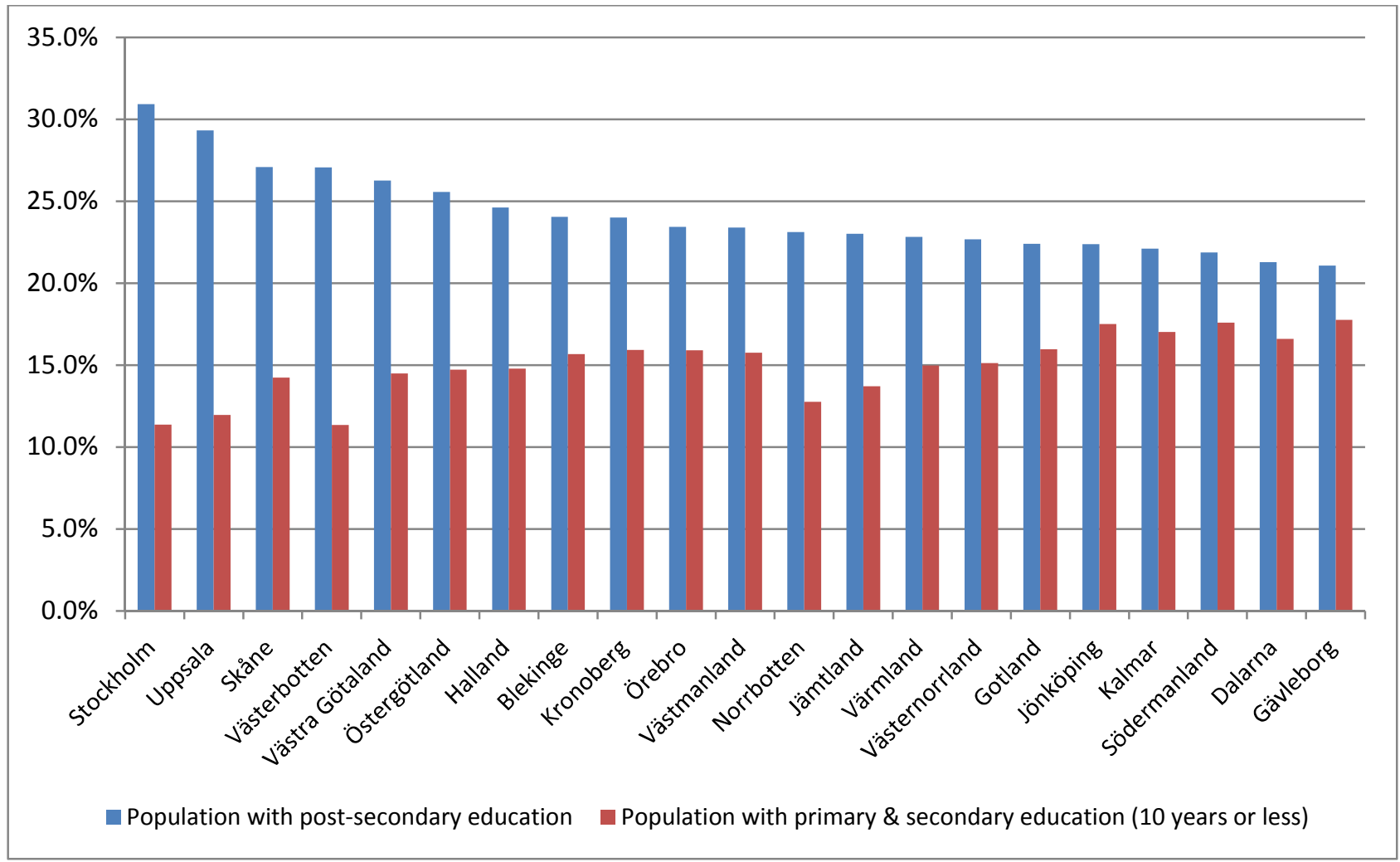

Source: Statistics Sweden

Given the trends in net inward international migration in Sweden, particular attention will need to be made to ensure that recently arrived immigrants are equipped with the skills needed to efficiently integrate into the local labour market. Recent research has shown that lower literacy proficiency and lower education leads to reduced employment prospects for immigrants (Bussi and Pareliussen, 2015). Therefore, Kalmar will need to ensure the recognition of qualifications for recently arrived immigrants and refugees, while also raising their level of skills - in particular literacy - and provide them with opportunities to learn the Swedish language (OECD, 2015a).

\section{Labour market in Kalmar county}

During the crisis, Sweden's unemployment rate increased by almost 3 percentage points, but part of this increase has now been reabsorbed. In October 2015, the unemployment rate was $6.7 \%$, well below the peak of $8.9 \%$ in 2010 . The employment rate (for the age group 15-64) has regained its pre-recession level and is the second highest among OECD countries (74.9\% vs 65.8\% OECD average in 2014). Although long-term unemployment has increased since the start of the crisis, it remains low in comparison to other OECD countries (OECD, 2015b).

Despite the recovery in the Swedish economy, limited labour market flexibility has restricted the access to jobs for young people with low qualifications as well as immigrants (OECD, 2015a). The youth unemployment has only declined to around $23 \%$ in 2014 in comparison to an OECD average of just under 
$15 \%{ }^{1}$. The share of youth who are Not in Employment or in Education and Training (the NEET rate) was around $7 \%$ in 2013, well below the OECD average (14.3\%), but higher than in the pre-crisis period.

In this context, the local labour market in Kalmar county seems to have been relatively more affected by the economic downturn than the broader Swedish economy. Unemployment figures indicate that the unemployment rate in Kalmar was below the Swedish average before the crisis, but increased dramatically between 2008 and 2009 and remained higher that the Swedish average until 2012. In the last two years, unemployment has started decreasing at a faster pace in comparison to the rest of the country. This trend continued also in 2015 as showed by recent data from the national public employment services.

Figure 1.7 Unemployment rate (\%), Kalmar county and Sweden, 2000-2014

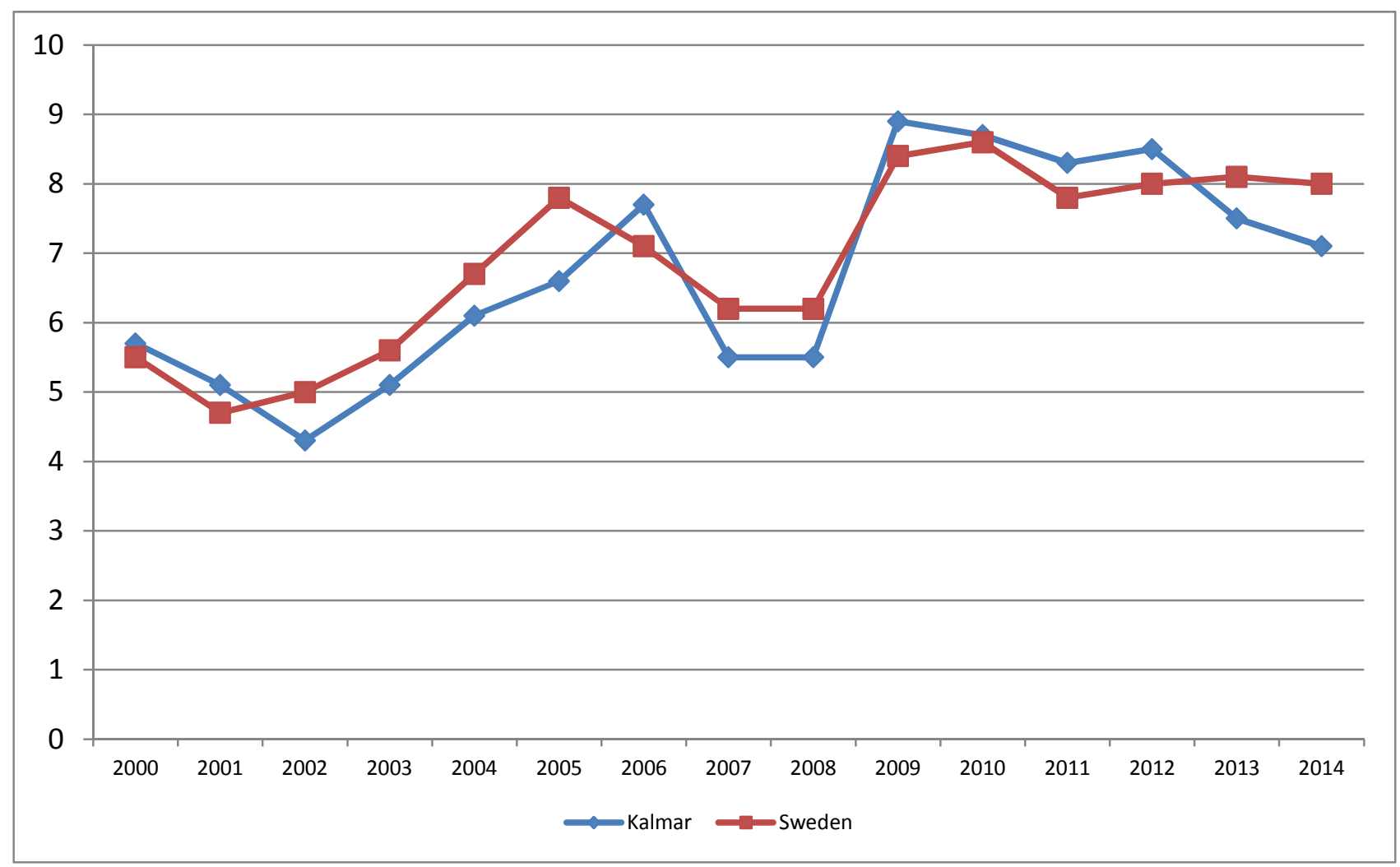

Source: OECD (2015), "Small regions, TL3: Regional labour market", OECD Regional Statistics (database).

DOI: http://dx.doi.org/10.1787/data-00528-en

In the last ten years employment rate for people aged between 20 and 64 was lower in Kalmar than in Sweden. Between 2005 and 2008, the employment rate increased at a robust pace in Kalmar. However, it fell dramatically as a consequence of the recent economic crisis and has not yet returned to its pre-crisis level. These trends may indicate that the local labour market in Kalmar is more vulnerable to economic fluctuations than other regions of Sweden.

1. As highlighted by Statistics Sweden, the high value of youth unemployment could be partially explained by certain national institutional characteristics and the structure of the Swedish education system. More information on international comparability could be found in this paper: http://www.scb.se/Statistik/_Publikationer/AM0401_2013A01_BR_AM76BR1304.pdf 
Figure 1.8 Employment rate (\%), Kalmar county and Sweden, 2005-2014

Population aged 20 to 64

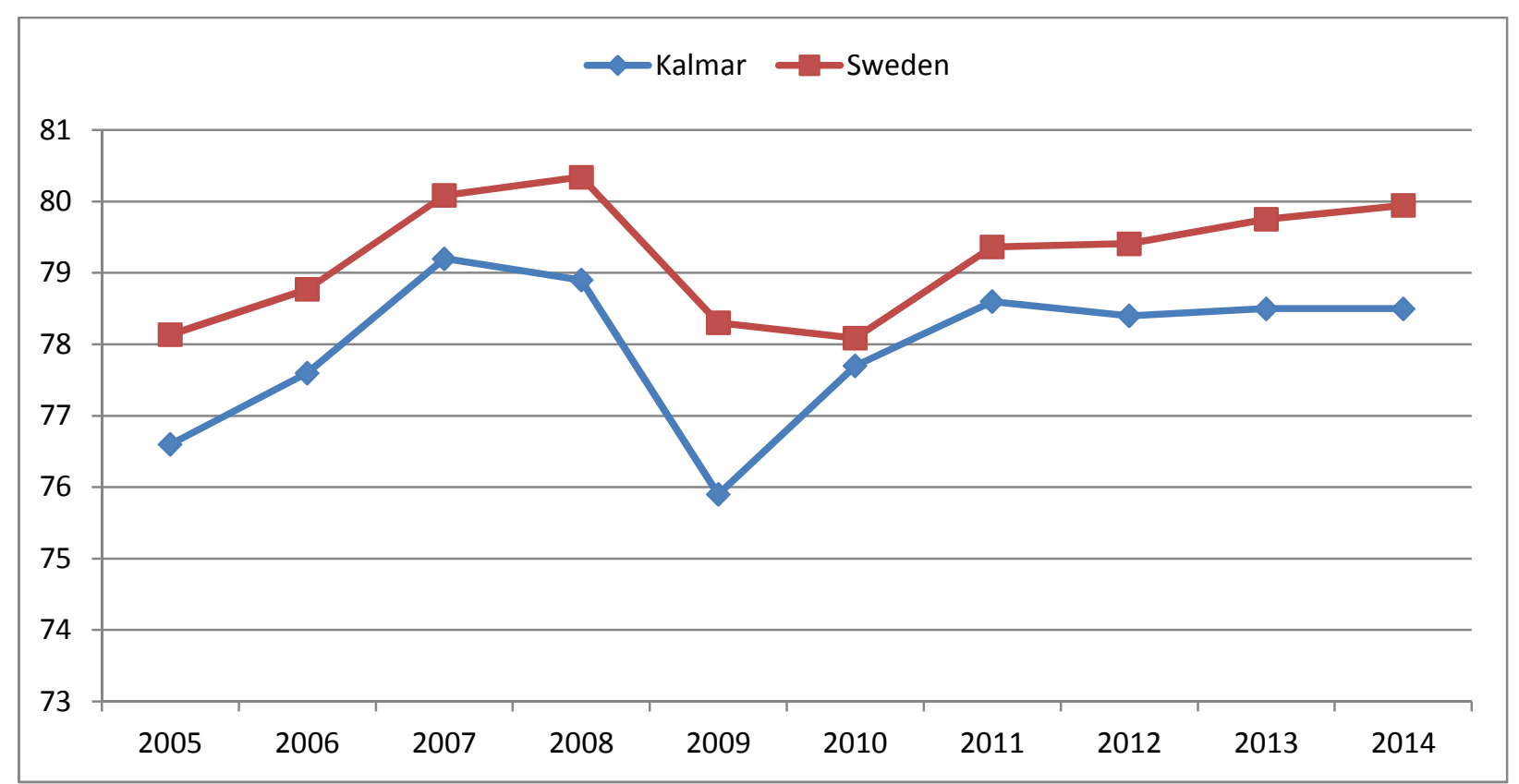

Source: Statistics Sweden

The public sector is the main employer in Kalmar county with $35 \%$ of the workforce working in the public administration, education and health sectors. Although the manufacturing sector had significant job losses in recent years following the closure of a number of firms including the Kalmar Varv shipyard as well as Kalmar Verkstad/Bombardier, the sector still represents $18 \%$ of total employment. The area of Kalmar is characterised by the presence of many small and medium-sized businesses in low value-added and low productive industries (OECD, 2012).

The biggest firm in the area is Scania, which produces trucks for the global market and has a major facility in Oskarshamn (North of Kalmar). Outside of Oskarshamn is a nuclear power plant which forms a hub for a more advanced labour market, including an institute for geological research. Employment in the service sector in Kalmar (54.6\%) is one of the lowest among Swedish counties. Within the service sector, the distributive trade, repairs, accommodation and food services activities sector, which includes many occupations in the tourism sector, represents one of the strengths of the local economy.

In terms of occupation, Kalmar has a low percentage of its population employed in high or medium skilled occupations (48.7\% in 2012 compared to 52.3\% on average in Sweden and 61\% in Stockholm). In Kalmar county there is a clear labour market segregation by gender, with men more likely to be employed in scientific jobs as well as physical occupations. On the other hand, women in the labour force tend to experience increasing polarisation between relatively skilled jobs in the education and health sectors or very low skilled jobs. Occupations in the care and sales sectors appear equally common for men and women. In general, this might imply that men are more likely to work in the private sector while women in the public sector. 
Figure 1.9 Employment by sector, Kalmar county, 2014

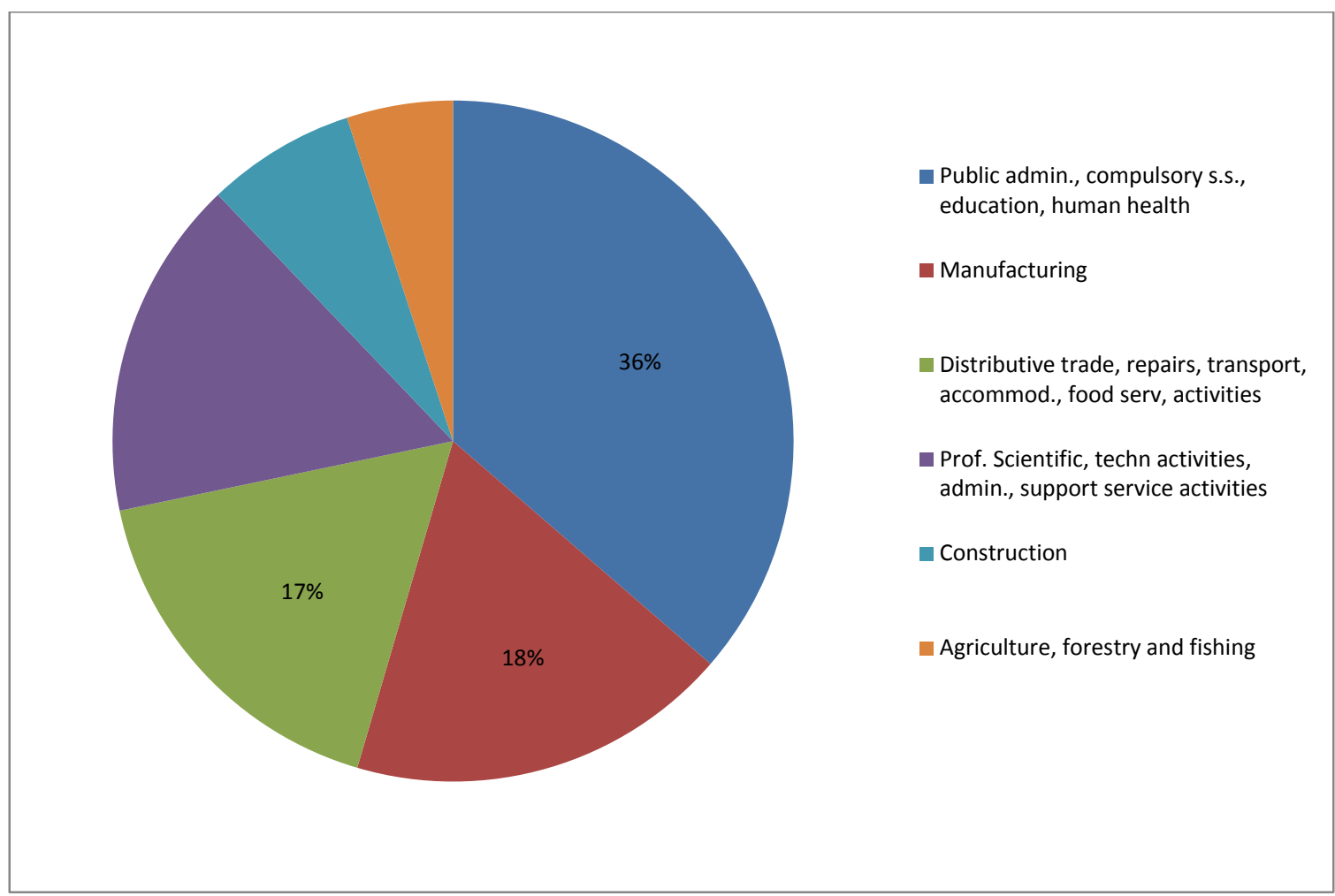

Source: Statistics Sweden

\section{Balance between skills supply and demand}

The OECD LEED Programme has developed a statistical tool to understand the balance between skills supply and demand within local labour markets (Froy, Giguère and Meghnagi, 2012). In the Swedish context, this tool can help to provide policy makers with an understanding of skills mismatches, which may occur at the sub-national level. It can inform place-based policy approaches at the local level. 
Figure 1.10 Understanding the relationship between skills supply and demand

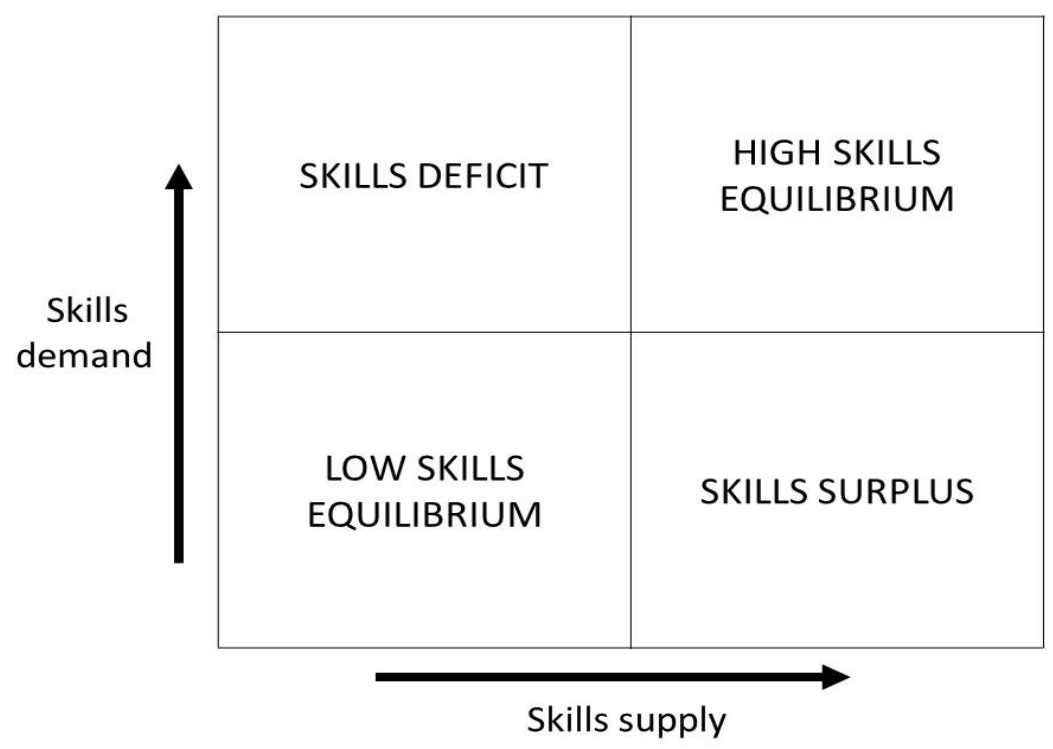

Source: Froy, F., S. Giguère and A. Hofer(eds.) (2009), Designing Local Skills Strategies, http://dx.doi.org/10.1787/9789264066649-en adapted from Green (2003).

Looking at the figure above, in the top-left corner (skills deficit), demand for high skills is met by a supply of low skills, a situation that results in reported skills gaps and shortages. In the top-right corner, demand for high skills is met by an equal supply of high skills resulting in a high-skill equilibrium. This is the most desired destination of all high performing local economies. At the bottom-left corner the demand for low skills is met by a supply of low skills resulting in a low-skill equilibrium. The challenge facing policymakers is to get the economy moving in a north-easterly direction towards the top-right corner. Lastly, in the bottom-right corner, demand for low skills is met by a supply of high skills resulting in an economy where what high skills are available are not utilised. This leads to the emigration of talent, underemployment, skill under-utilisation, and attrition of human capital, all of which signal missed opportunities for creating prosperity.

\section{Box 1.1 Explaining the diagnostic tool}

The analysis is carried out at Territorial Level 3 regions (regions with populations ranging between 150 000-800 000). The supply of skills was measured by the percentage of the population with post-secondary education. The demand for skills was measured by the percentage of the population employed in medium-high skilled occupations and the productivity per worker. The indices are standardised using the inter-decile method and are compared with the national median. Further explanations on the methodology can be found in Froy, Giguère and Meghnagi, 2012.

Source: Froy, F., S. Giguère and M. Meghnagi (2012), "Skills for Competitiveness: A Synthesis Report", OECD Local Economic and Employment Development (LEED) Working Papers, No. 2012/09, OECD Publishing. doi: 10.1787/5k98xwskmvr6-en

The map below shows the result of the skills diagnostic tool at the counties level in Sweden. Kalmar county is in a low skills equilibrium, which indicates a relatively low level of both skills supply and demand compared to other Swedish counties. 
Figure 1.11 The balance between skills supply and demand in Swedish counties, 2013

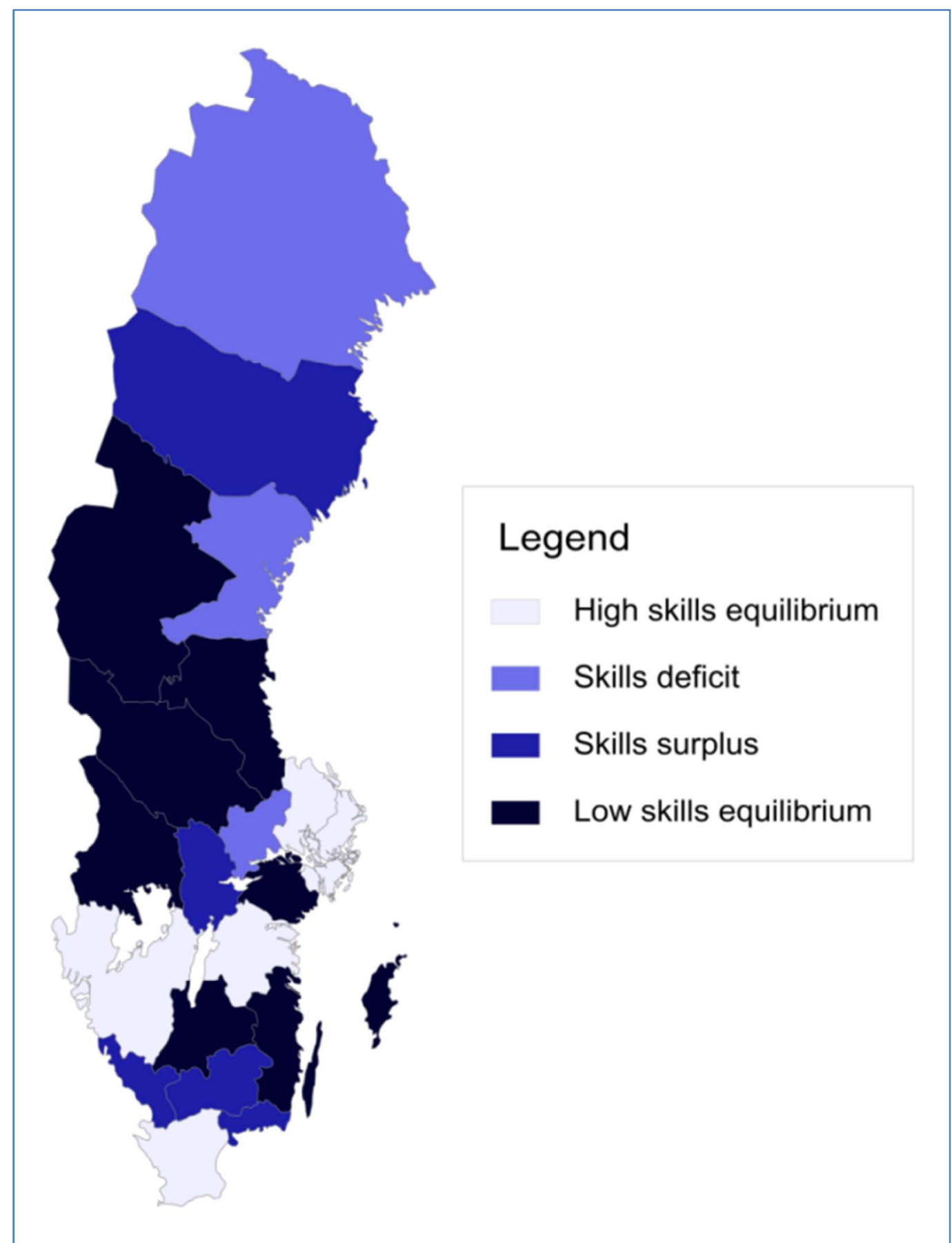

Source: LEED analysis using Statistics Sweden data

When investigating Kalmar county's exact location within the low skills equilibrium, it is interesting to note that it is very close to a skills deficit. This indicates that although both the supply and demand of skills should be improved to move towards a high skills equilibrium, raising the level of skills supply and retaining skilled people is the most important issue to be addressed. 
Figure 1.12 Skills supply and demand, Swedish counties, 2013

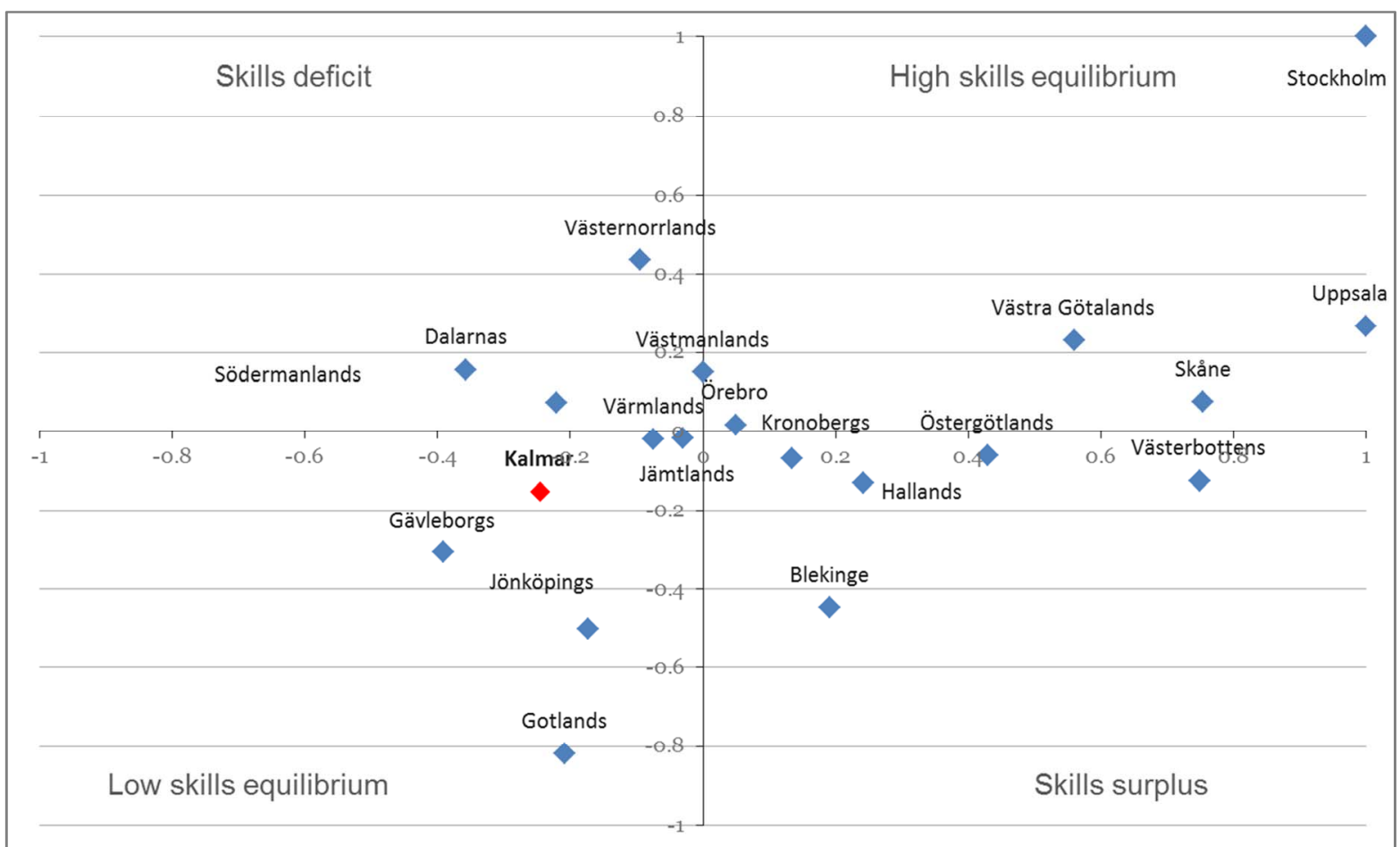

Source: LEED calculations based on Statistics Sweden data

\section{Summary}

The county of Kalmar has lost population in recent years, mainly due to internal emigration. The share of working age population is lower than in the rest of Sweden, thus implying a risk of labour shortage. This is somewhat compensated by increased international migration flows of younger populations. Between 2001 and 2015, the share of foreign-born residing in the county of Kalmar increased from $6.4 \%$ to $11.7 \%$. Attracting skilled individuals through international immigration and integrating these new populations into the local labour market is a key issue for the county.

The above average share of employment in the public, manufacturing and agriculture sectors indicate that Kalmar has kept a relatively diversified economic base. Labour productivity in Kalmar is relatively low in comparison to other counties in Sweden, as is the share of employment in medium-high skilled occupations. These are clear indications of low demand for skills by employers. The supply of skills in Kalmar is also relatively limited because of the low level of educational attainment. These characteristics result in a low skills equilibrium for the county in comparison to other Swedish counties. 


\section{Section 2}

\section{BOOSTING JOB CREATION ASSESSMENT FINDINGS}

This section highlights findings from the boosting job creation dashboard in Kalmar. The findings are discussed through the four thematic areas of the review: 1) Co-ordination between employment, skills and economic development policies; 2) Creating productive economies; 3) Supporting entrepreneurship and economic development; and 4) Ensuring growth is inclusive. 


\section{Results from the assessment tool}

This section of the report presents the key findings from the in-depth fieldwork and highlights successful initiatives that have been introduced in Kalmar county as well as organisations that are doing innovative work. The overall assessment identifies a robust range of programmes and policies to support job creation and employment. This, of course, does not mean that the county is without challenges when it comes to boosting local employment and economic development opportunities (as demonstrated in section 1 of this report).

Figure 2.1 shows the overall results from the boosting job creation assessment. The assessment assigns a score of between 1 (low) and 5 (high) based on the strengths and weaknesses of the policy approach. These results have been presented and discussed by local stakeholders in Kalmar during an OECD workshop to ensure their validity. In this section, the results from each of the priority areas is presented and discussed sequentially. Innovative programmes and policies are highlighted to demonstrate what actions are being taken by Kalmar to boosting local employment and economic development.

Figure 2.1 OECD Gap Assessment Results for Kalmar

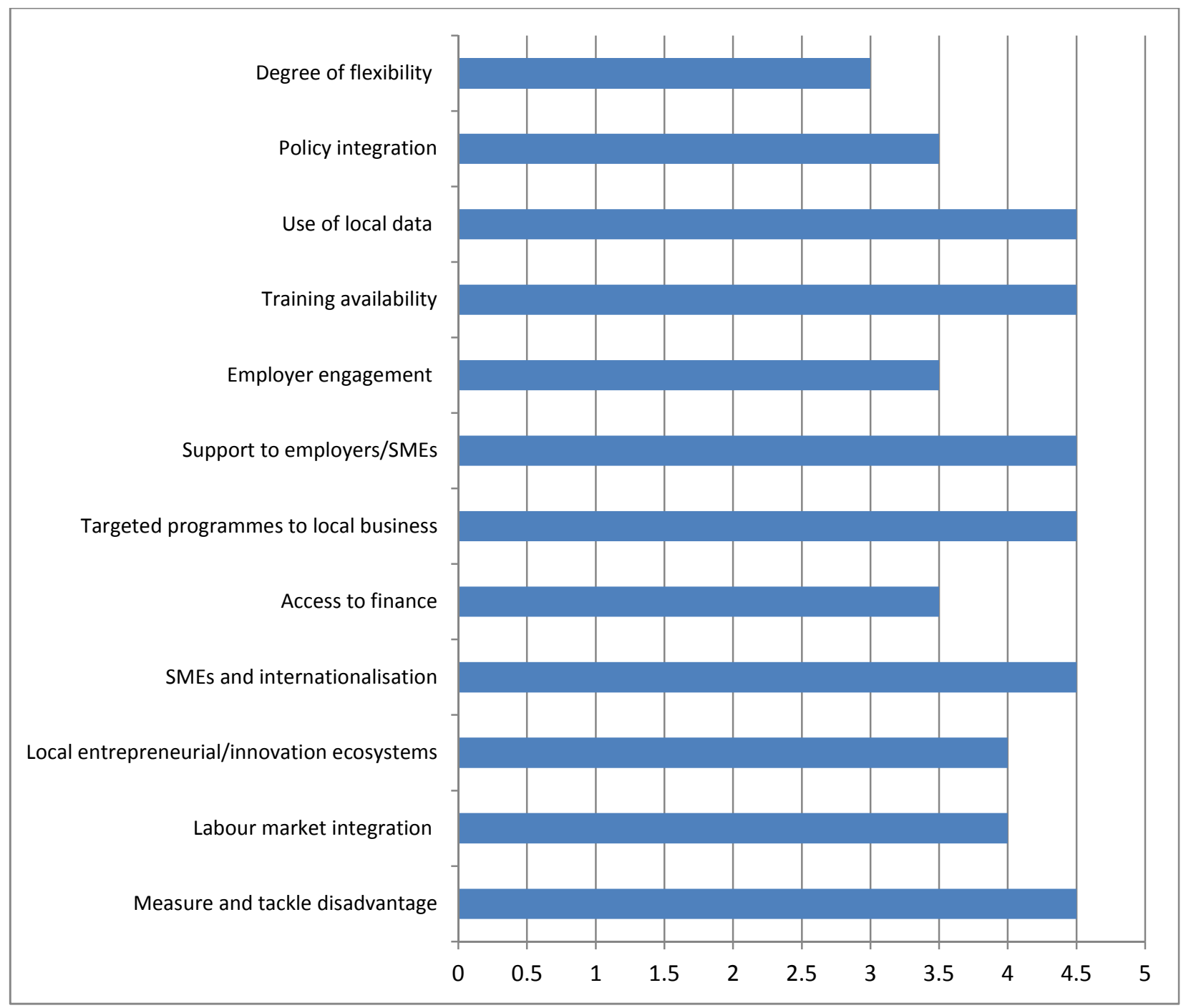




\section{Co-ordination between employment, skills and economic development policies}

Figure 2.2 Assessment results for co-ordination between employment, skills and economic development policies

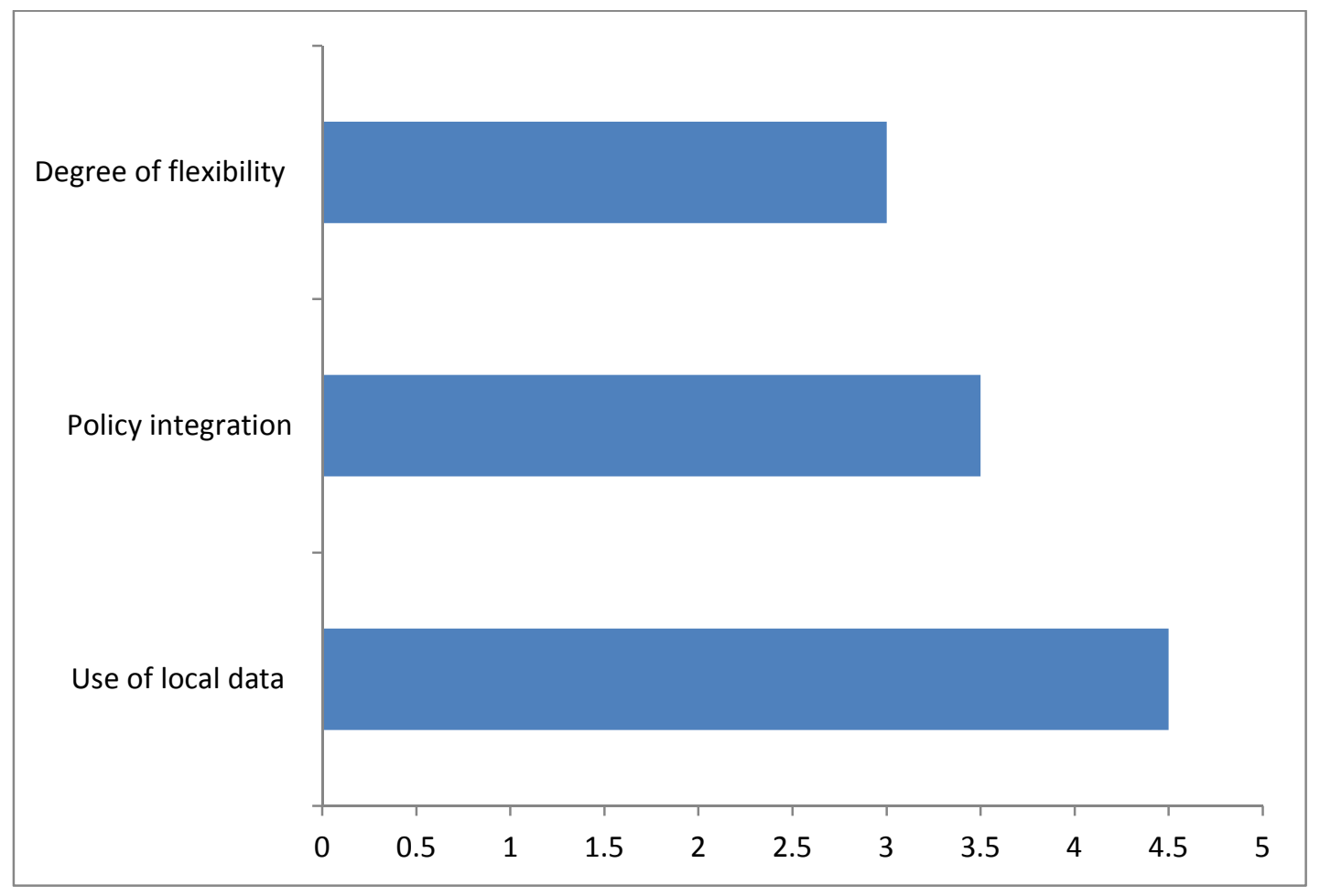

\section{Degree of flexibility in designing and implementing policies and initiatives}

The OECD defines flexibility as 'the possibility to adjust policy at its various design, implementation and delivery stages to make it better adapted to local contexts, actions carried out by other organisations, strategies being pursued, and challenges and opportunities faced' (Giguère and Froy, 2009). Flexibility deals with the latitude that exists in the management system of the employment system, rather than the flexibility of the labour market itself. The achievement of local flexibility does not necessarily mean that governments need to politically decentralise (Giguère and Froy, 2009). Governments just need to give local institutions sufficient latitude when allocating responsibilities in the fields of designing policies and programmes; managing budgets; setting performance targets; deciding on eligibility; and outsourcing services.

Similarly to the rest of Sweden, flexibility is a difficult issue in Kalmar county because employment policy is centrally designed and uniformly carried out across the country. Compared to other OECD countries, local flexibility in the management of employment policies is low. Employment policies take a national perspective on the labour market with an emphasis on mobility rather than re-training people to stay in a particular area. Retraining can be offered if there is an identified skills shortage. Employment programmes are designed nationally by the government and with heavy involvement from the Parliament in the specific details. The whole suite of about a dozen programs has to be implemented locally. Work processes are streamlined to ensure that clients are treated in a uniform fashion across the country (OECD, 2015).

In the area of budget management, budgets are set nationally with almost no possibility to move funds between allocated programme budget lines. Funding can be redistributed geographically within the 
regions of the public employment service (Marknadsomraide), but not across the programmes without prior permission by the central level. Accountability is almost entirely upwards in the hierarchy and to the government. The local employment agency reports to other local stakeholders in an effort to coordinate and collaborate with them.

Outsourcing is carried out nationally, based on an inventory of the local needs. Outsourcing of operations can be an instrument to strengthen flexibility, but it can also make it more difficult to adjust pre-set programmes to individual needs.

Overall, the local offices of the public employment service (Arbetsförmedlingen) are able to provide services to most individuals who come to their offices. Services are targeted towards the unemployed and to those who are the furthest away from the labour market. People with a job can be treated as transfer applicants (ombytessökande), which is important for Arbetsförmedlingen in its relationship with local employers.

A large share of vocational education and training is provided by Arbetsförmedlingen through their contractors. Local stakeholders (e.g. employers) can request special training programmes to meet local needs but the approval process can be burdensome. Contracting takes a lot of time due to frequent legal action/obstruction. It is very common for the choice of contractor to be challenged through the administrative courts. The service can be provided much quicker when there is already an outsourced programme in place.

In Kalmar, eligibility for subsidised training for the unemployed through Arbetsförmedlingen is decided nationally and restricted to specific target groups. The local governments can provide similar types of training through Komvux, with less regulation, which means that it can be developed and delivered more efficiently. Programmes are generally run in-house by secondary schools that are a part of Komvux. Volumes and eligibility depend on local decisions. Additional programmes and courses are offered by the non-traditional boarding schools (folkhögskola), evening schools (studieförbund), universities and private companies.

Training is delivered by a variety of providers, including not-for-profit actors. The coordination with the public training system is good for some segments of the labour market like migrants, where the council on integration (Integrationsrådet) is a forum for coordination. Coordination in general is more on an ad hoc-basis.

Delivering joint programmes at the local level can be a challenge due to the difficulties of collaborating with the national employment service and local governments. Restrictions on the employment service mean that it is impossible to co-fund programmes with local governments. Employment and training programmes could be delivered differently if there was more flexibility and collaboration across organisational boundaries.

\section{Degree of integration between employment, skills and economic development}

Policies are to some extent coordinated through the regional development strategy (see Box 2.1). Programmes are often integrated but this is done on an ad hoc basis. More extensive coordination relates to skills development as well as to migrants and unemployed youth. Policy integration in the areas of employment, skills and economic development is not always well developed. There is some cross referencing between the three areas when it comes to collaboration to address youth unemployment. Joint strategies are also developed by the Regional Council in Kalmar County (Regionförbundet) after consultations with local governments and public agencies in the framework of the regional development 
strategy (RUS). Arbetsförmedlingen also collaborates with larger local governments in Kalmar to develop such strategies.

\section{Box 2.1 Kalmar's Regional Development Strategy}

The Regional Council in Kalmar county (Regionförbundet) has held the leadership role for regional economic development since 1997. It was set up as an indirectly elected organisation, owned by the local governments (kommuner) and the regional government (landstinget) with the purpose of integrating the development perspectives of the sub-national levels of government, while taking over the leadership role from the prefecture-like organisation (länsstyrelsen).

Regionförbundet is mandated by the government to produce a regional strategy which national agencies and other public organisations have to take into account in their operations in the region. The regional strategy focuses on a number of areas including skills, business development and infrastructure development. There is a large number of partners in the area of skills development and job creation,:

- Arbetsförmedlingen, the public employment agency, runs a set of standardised services for the unemployed;

- National agencies other than Arbetsförmedlingen are involved in skills development and training. Tertiary education is provided by the national government through Linneus University and the agency for higher vocational education (Yrkeshögskolan), which runs a few programs in the region. Activities are funded by Försäkringskassan.

- The regional government (landsting) funds additional skills development and training institutes, such as the non-traditional boarding schools (folkhögskolor).

- Local governments (kommuner) run programs for the unemployed who are not eligible for support from Arbesförmedlingen, for example migrants who don't speak the language. Local governments are also major providers of skills development and training through schools for the young and for adults (Komvux). They have a general responsibility for the welfare of its citizens and are highly independent, for example by raising their own taxes.

- The wider economic development agenda is based on collaboration with the agency for infrastructure and transport (Trafikverket), the agency for regional growth (Tillväxtverket) and the agency for applied research and development (Vinnova). Almi is a national/regional organisation for loans to growing firms (SMEs).

- The European Regional Fund and the European Social Fund provide funding on a project-basis in collaboration with and co-funded by Swedish organisations.

A number of associations work with business development and skills development, ranging from general business associations to more specific partnerships to develop technical training colleges.

Partnerships are in place between Arbetsförmedlingen and skills development programmes provided by the local governments through Komvux. There is potential to develop these collaborative frameworks further. In Kalmar county, there is evidence of programme coordination and budget allocation to joint projects. Relevant examples include the Campus Västervik, where post-secondary vocational education is provided to meet local needs and the doubling of secondary education in Oskarshamn in order to meet the demands of the local employer Scania. 


\section{Degree of utilisation of local data in evidence-based policy making}

Policy is data driven and local initiatives are based on robust evidence. The local programmes and strategies refer to a broad range of locally specific data that are updated on a regular basis. Regular surveys or assessments are carried out to ascertain the types of skills available within the local population.

Annual surveys are carried out with local employers to assess their skills needs and the existence of skills gaps and shortages. The results of the survey feed into employment and training programmes and evaluation data is used and is regularly referred to in policies and programmes. A wealth of labour market information is available from Statistics Sweden and this information can often be disaggregated to the county and municipal level.

Previous OECD research has highlighted the robust evaluation culture in Sweden (OECD, 2015). There are many evaluation agencies, which undertake research which informs policy development processes. This includes evaluations of employment policies (IFAU), regional development policies (Tillväxtanalys), as well as agencies for the evaluation of secondary (Skolverket) and tertiary education (formerly Högskoleverket, now Kanslersämbetet). Further evaluations are provided by the agency for public management (Statskontoret) and the National Audit Office (Riksrevisionen). The Institute for Future Studies (Institutet för Framtidsstudier) and the Ministry of Finance's expert group on the public economy (ESO) also carry out a number of evaluations.

Travel to work areas (Arbetsmarknadsområde) are constructed statistically by identifying the strongest patterns of commuting. Most Swedish counties consist of just a few such areas, indicating that the cities are well-integrated with surrounding areas. There is some fit between administrative boundaries (counties) and the local travel to work area. An OECD Territorial Review conducted in 2012 demonstrated how inter-county commuting patterns have undergone modest changes over the last two decades. In terms of headcount, the share of residents commuting outward from Kalmar has increased by 2.4 percentage points $(\mathrm{OECD}, 2012)$ since 1993. The great bulk of the increase in commuting is to destinations outside the region and towards other metropolitan areas of Sweden. 


\section{Creating productive economies}

Figure 2.3 Assessment results for creating productive economies

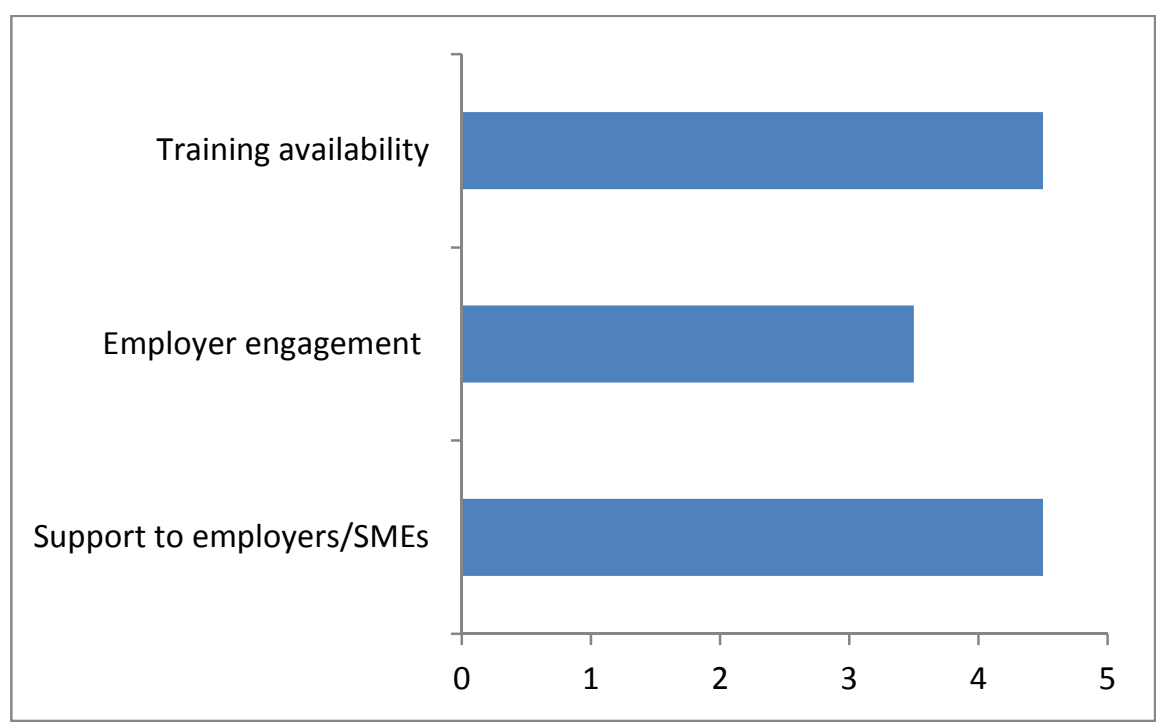

Extent to which training is available in a broad range of sectors, flexible and accommodating the needs of workers and unemployed individuals

Training is generally available in bigger towns. The lack of well-developed transport infrastructure represents one of the major obstacles in a number of remote areas within Kalmar county. The volume of courses available is rather high. In the bigger towns, like Kalmar, there is a sufficiently broad range of courses available locally so students can choose whether to study locally or go elsewhere. However students from other parts of the county are forced to travel elsewhere in order to find the courses they need. Women seem to be more willing than men to move to areas with better education provision. However, difficulties related to commuting are identified as a major obstacle for skills development, for example by Campus Västervik.

\section{Box 2.2 Campus learning facilities}

The campuses of Västervik, Vimmerby and Hultsfred were created with the objective of offering learning facilities to make post-secondary and other education and training courses more accessible outside bigger towns. These centres offer courses and programmes through distance education and other general services for students. Courses are provided by three universities and some private providers. The universities are in charge of an introductory course in law as well as full programs for nurses and childcare.

Programmes to train technicians in process-oriented production in the industrial sector are provided through Yrkeshögskolan. These centres have been set up by local initiatives to reach out to a general audience, including individuals who are unwilling to move to the bigger towns. It is estimated that many students involved in this initiative would not have undertaken a similar programme if it wasn't available locally.

These centres work closely with local employers to ensure that local needs are met and that those people who take the courses will also find jobs afterwards. The results are promising with almost all graduates (96\%) finding a job after participating in the programme.

Source: http://www.vastervik.se/Campus-Vastervik/ 
Different types of training exist in the regions including: 1) subsidised training to the unemployed; 2) subsidised training for workers which is provided by employers and sometimes co-funded by the ESF; 3) basic skills training, including catch-up programmes at the primary school level which is provided by nontraditional boarding schools known as Folkhögskola; 4) modular training, which is provided by Linnaeus University and others as distance courses and as after hour training (e.g. evening, half-pace on campus). There are no secondary vocational schools run by companies in the region. Yrkeshögskolan is a postsecondary form of education that combines theoretical and practical studies in close co-operation with employers and industry and currently operates four programmes in the region.

Previous OECD work in Sweden has demonstrated the innovative nature of Yrkeshögskolan programmes, which are a vocational post-secondary education pathway with some similarities to polytechnics. They are run in short cycles and on a project basis. Funding decisions are made nationally based on a calculation of labour market needs while the programmes are delivered by many types of education providers, including in conjunction with other public systems (OECD, 2014).

\section{Box 2.3 Linnaeus Technical Centre in Kalmar}

The Linnaeus Technical Centre is a project which provides several arenas for collaboration between the local engineering industry and Linnaeus University. The increased visibility of engineering firms in the regions (Kalmar and Kronoberg) is believed to lead to a greater interest among students and increased recruitment by the firms. At the same time it will provide additional funding for research at the University.

Linnaeus University (Campus Kalmar and Campus Växjö) is the hub of the project, with local "nodes" in four locations across the two regions. The local nodes work with research and development, skills development and building relations with students. The project is co-funded by the two regions, the university and the European Regional Development Fund.

Source: http://lnu.se/forskargrupper/linnaeus-technical-centre

\section{Degree of employer engagement in orienting skills development to demand and extent to which training meets business needs}

Despite the broad range of training available, employers report problems with training curricula not being aligned to their needs. There are specific programmes and initiatives in place to increase workplace training. Examples are found in the general effort to increase the on the job-training ("praktik"). The term praktik is more broadly used to cover all sorts of on the job-training. It can be paid, unpaid or with benefits such as subsidised student loans, if it is part of a programme in higher education. There can be additional subsidies for the employers, for example in the apprenticeship system, where employers are expected to provide workbased learning. Without subsidies, it can be a form of cost-sharing with the companies, as in the higher vocational education.

There is a specific programme by Arbetsförmedlingen to provide such positions to unemployed youth. There are also employers' organisations and others who assist in recruiting interested companies as well as interested youth. There are specific programmes and initiatives in place to increase workplace training. This is done by industry-specific collaborative arrangements, also known as "nodes". Workplace training is conducted by the firms themselves when they pay public providers of skills development to give courses within the companies.

Customised training is available in a number of sectors through the industrial programmes of the secondary vocational schools. It is also conducted by public providers to companies that insource courses and programmes. Apprenticeships (lärlingsplatser) have been discussed for a long time and have been 
introduced as an alternative to vocational secondary school. Apprenticeships are offered in a narrow range of sectors (e.g. including services), primarily the construction sector, and are taken up by fewer than $20 \%$ of young people (aged 15-24) (OECD, 2015).

Adult education institutions and universities offer careers advice geared to local industries. This is done for example by the collaboration coordinators (Samverkanskoordinatorer) by Arbetsförmedlingen. Additionally, the skills of secondary schools graduates do not seem to meet the needs of the employers but there are active attempts to link graduates to local industries, such as through the career fairs known as Arbetsmarknadsmässa (labour market fair).

\section{Degree of support to employers/SMEs in maximising skills utilization, improving work organisation, human resource management, workforce planning and skills development}

Larger companies can help local SMEs develop skills, such as through the employers' ring in the city of Kalmar. Sometimes a smaller company is a staffing company (bemanningsföretag) which provides staff on a contract and also invests in skills development and takes on business risk as part of a supply chain arrangement. One area of collaboration between smaller and bigger firms is export promotion, which is relatively common in the ICT sector. A special arrangement is the Information Engineering Center (IEC), tied to Linnaeus University. More recently a strategy was put in place also for the food sector, to promote a "from soil to table" value chain perspective.

\section{Box 2.4 A local economic development strategy for the food sector}

In September 2015, the Regional Council in Kalmar county, together with the County Administrative Board (Länsstyrelsen) and the farmers' association (LRF), approved a strategy to further develop the food sector. More than 900 people were involved in the development of the strategy and a steering group contributed to the identification of the long term goals and activity planning for the next 5-10 years. One of the objectives of the strategy is to provide the foundation for investment in specific projects by the European Regional Development Fund and others.

The strategy is based on a set of studies on the wider concept of green industries, meaning industries that are based on land, woods, gardens or the rural environment, including fishing. The strategy is based on an analysis of strengths, weaknesses, opportunities and threats. It will be implemented through seven core activities, including better use of the existing support systems for firms, targeted support for research and development and a working group for skills development. The working group will look into the concept of a food college, which in Sweden refers to an organised collaboration of firms in the industry with the providers of vocational education (primarily in secondary education, but also tertiary levels). One activity is to provide external quality control for the training programmes to ensure that they meet industry standards.

Source: http://www.rfkl.se/sv/Verksamheter/Naringsliv-Tillvaxt/Livsmedelsstrategi/

The public sector works with employers to improve skills utilisation and work organisation. Programmes, networks and schemes exist, involving major employers and sectoral organisations. These organisations assist companies to grow, for example through loans and grants and support to improve skills utilisation and work organisation. Particular support is given to SMEs to stimulate skills development by adapting training programmes to the needs of smaller firms. There is a range of strategies to improve work organisation and labour productivity especially in the tourism and food sectors. Brokers to help engage SMEs in skills and knowledge development also exist in the region.

Additional services are provided by the Information Engineering Center (IEC), the coordinators for industries, as well as the "nodes" and the rural academy (Landsbygdsakademin) which is funded by the European Program for Rural Development. Optional entrepreneurship courses are provided at Linnaeus 
University, Campus Västervik and in some programs by Arbetsförmedlingen. In secondary schools, pupils are offered the opportunity to start a company through Ung Företagsamhet (UF, Young entrepreneurs).

\section{Box 2.5 Information Engineering Center}

The Information Engineering Center (IEC) is an outreach project by Linnaeus University. It is set up as a membership organisation made up of researchers, SMEs and public sector organisations. The purpose of IEC is to improve knowledge and research in information and communication technologies (ICT) in firms, while also providing the researchers with a better understanding of companies' needs. It is an arena for networking, by arranging formal and informal meetings, and it gives companies the opportunity to commission research projects related to real problems that local firms face.

There are now 15 specialised groups of users within IEC in the fields of programming, data mining and visualisation.

Source: http://Inu.se/forskargrupper/information-engineering-center-iec

\section{Supporting entrepreneurship and economic development}

Figure 2.4 Assessment results for supporting entrepreneurship and economic development

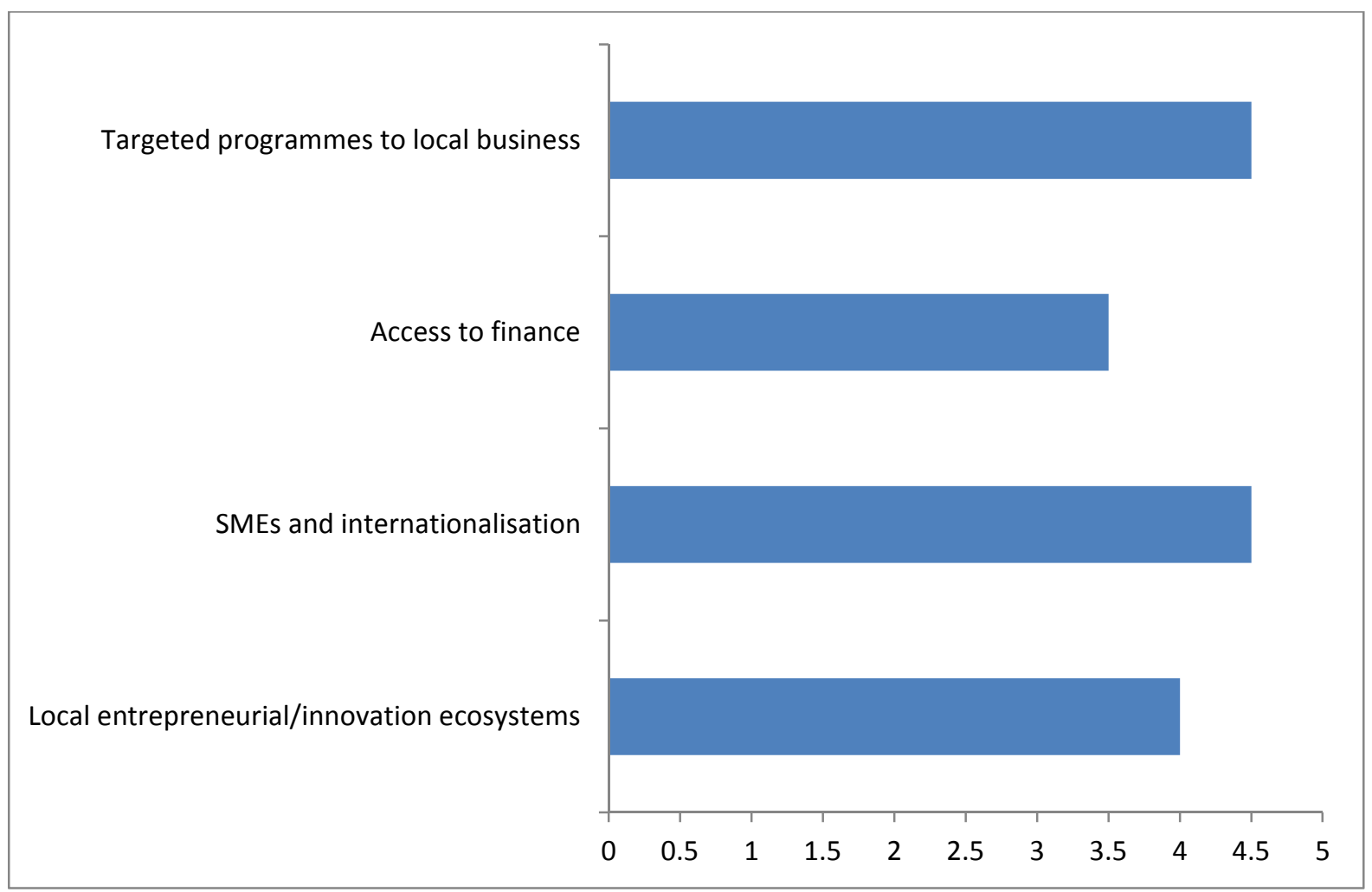

Extent to which programmes and services are adapted to local business demographics and profiles to address SME needs

When looking at the SME sector in Sweden, one can see that they account for $99.8 \%$ of all firms and employ about $65.4 \%$ of the total workforce (OECD, 2015). Locally, SMEs are a critical source of job creation and a prominent feature of the local economy in Kalmar county; therefore it is important to 
ensure that programmes and services are responsive to their needs. Kalmar county has a broad spectrum of sectors based on trade, commerce and manufacturing in areas such as automotive components, biotechnology, wood for housing and furniture, and environmental energy techniques. There are also several well-known industrial clusters for crystal, furniture and aluminium.

There are well developed support mechanisms for SMEs in relation to business development and work organisation. Furthermore, employment programmes and initiatives are targeted to important local employment sectors by Arbetsförmedlingen. Analysis has also been carried out by regional development agencies in collaboration with other organisations to inform a broad range of employment programmes. This has been part of regional development policy in most Swedish regions, through the overall planning documents (RUS, RUFS) or through the partnerships for skills development.

However, the share of workers in low-skilled, low value added production is a structural issue that limits the county's growth potential. Kalmar is near the bottom when looking at the share of workers in professional and scientific activities across Swedish counties (OECD, 2012). During the last few years, there has been some expansion into more service and technology oriented sectors.

\section{Degree of access to finance by SMEs}

Looking at SME lending, it is difficult to obtain specific data on the Kalmar county level. At the national level, OECD research has found that there was a decline in the Swedish average of total business loans and SME loans in 2010. Whilst lending to businesses and SMEs recovered in 2011, this level is still below the 2009 average (OECD, 2015). The quarterly surveys of the Swedish Governmental finance company, ALMI, show that the share of bank managers who reported an increase in loan volumes to businesses reached a low in the last quarter of 2008, at the most critical moment of the financial crisis. The situation slightly improved following the crisis but never fully recovered, which placed pressure on the SME sector. The most recent data from the survey show that business loans are gradually increasing.

Over the period of 2007 to 2012, the year of 2008 marked a low point where SME loans accounted for only $7 \%$ of all business lending. However, this proportion has since climbed to almost $12 \%$ in 2012 . The increase is explained primarily by an increase in the share of short-term loans (OECD, 2015).

In Kalmar, entrepreneurs have access to support and funding through both national programmes and local initiatives. However, according to the OECD roundtable, this funding is not considered sufficient to meet demand. There is a broad range of public start-up funding programmes in the region. However, they too are considered insufficient to meet demand and entrepreneurs seem to have difficulties in accessing them. Funding is provided by organisations such as Almi företagspartner and by the rural development programme (Landsbygdsprogrammet). The Regional Council in Kalmar county provides vouchers.

\section{Extent to which SMEs are helped to benefit from internationalisation opportunities}

In Sweden, export credit guarantees are provided through the Swedish Export Credit Corporation (EKN), which offers guarantees up to $75 \%$ of total transactions. During 2012 the volume of guarantees reached SEK 2.2 billion, continuing the decrease seen in previous years, from SEK 2.9 billion in 2010 to SEK 2.6 billion in 2011 (OECD, 2015).

In Kalmar county, support and advisory services for the internationalisation of SMEs are available from most business representative and business support organisations. Examples are Almi, the council for export promotion (Exportrådet) and the chamber of commerce (Handelskammaren). SME vouchers can be used for this purpose. There are initiatives to encourage SME internationalisation through coaching by 
large companies, but SMEs have difficulties accessing them. One successful experience is the coaching provided by the Regional Council office in Shanghai, where SMEs are helped to access the Asian market.

\section{Degree of development of local entrepreneurial/innovation ecosystems and extent of knowledge-sharing}

Looking at business start-up data and trends, one can see that Kalmar county lags behind other regions of Sweden. Figure 2.5 shows that Kalmar has below-average entrepreneurial activity among the working age population. In 2013, start-up rates in Kalmar were the fifth lowest among Swedish regions.

Figure 2.5 Start-up rates per 1000 inhabitants aged 16-64, 2013

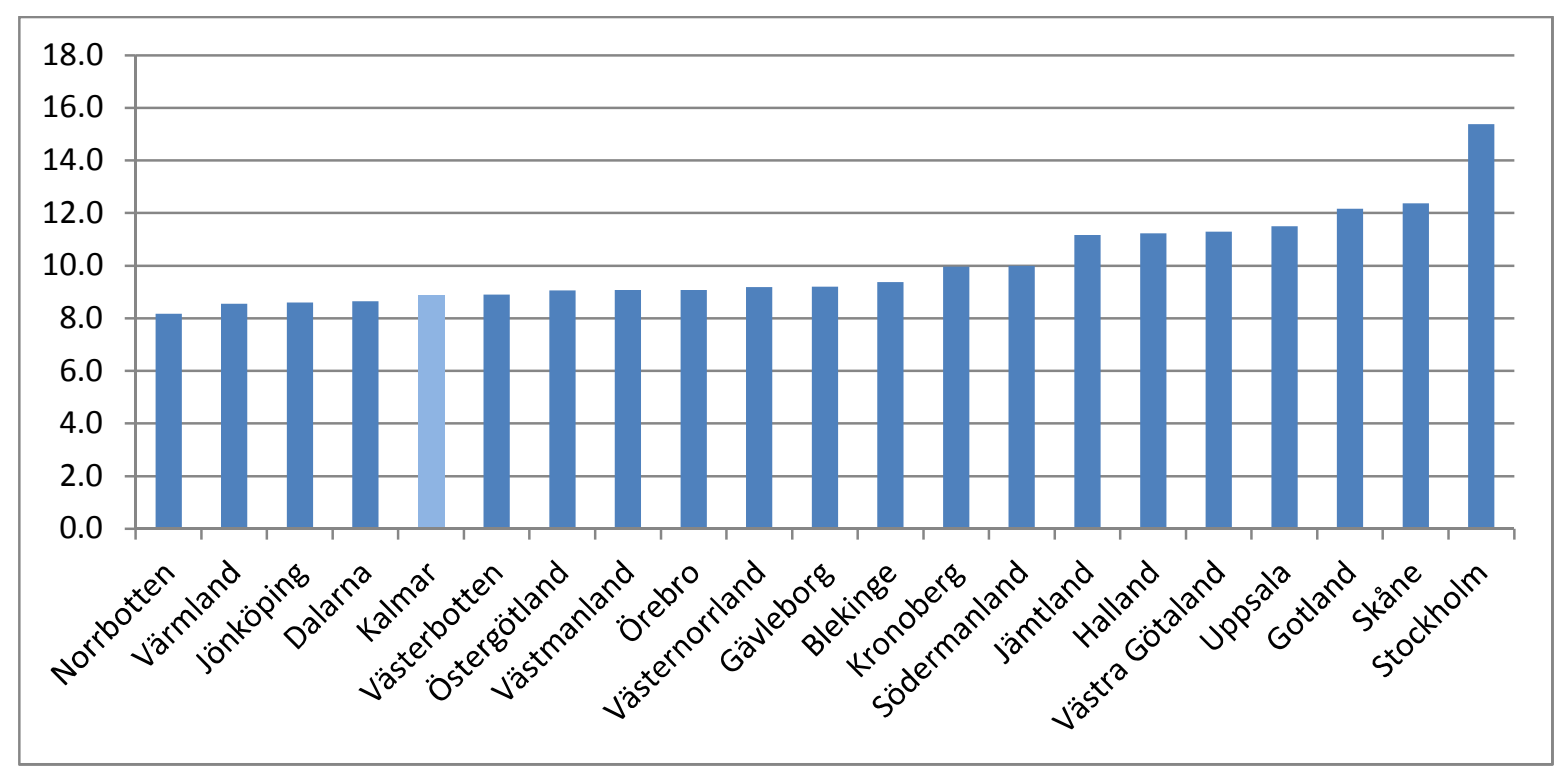

Source: Swedish Agency for Growth Policy Analysis (Tillväxtanalys)

A growing number of young people view entrepreneurship as a desirable career path. In many OECD countries, much effort is focused on how to stimulate youth entrepreneurship activities through stronger networking and mentorship activities. Efforts are also being made to embed entrepreneurship skills into the training and university system. Looking at youth entrepreneurship activity, one can see that the trend is similar in Kalmar county as it was for the working age population (see Figure 2.6). When analysing this data, Kalmar's position slightly improves but it remains sixth from the bottom in terms of stimulating start-ups among the youth population. 
Figure 2.6 Start-up rates per 1000 inhabitants aged less than 30 years, 2013

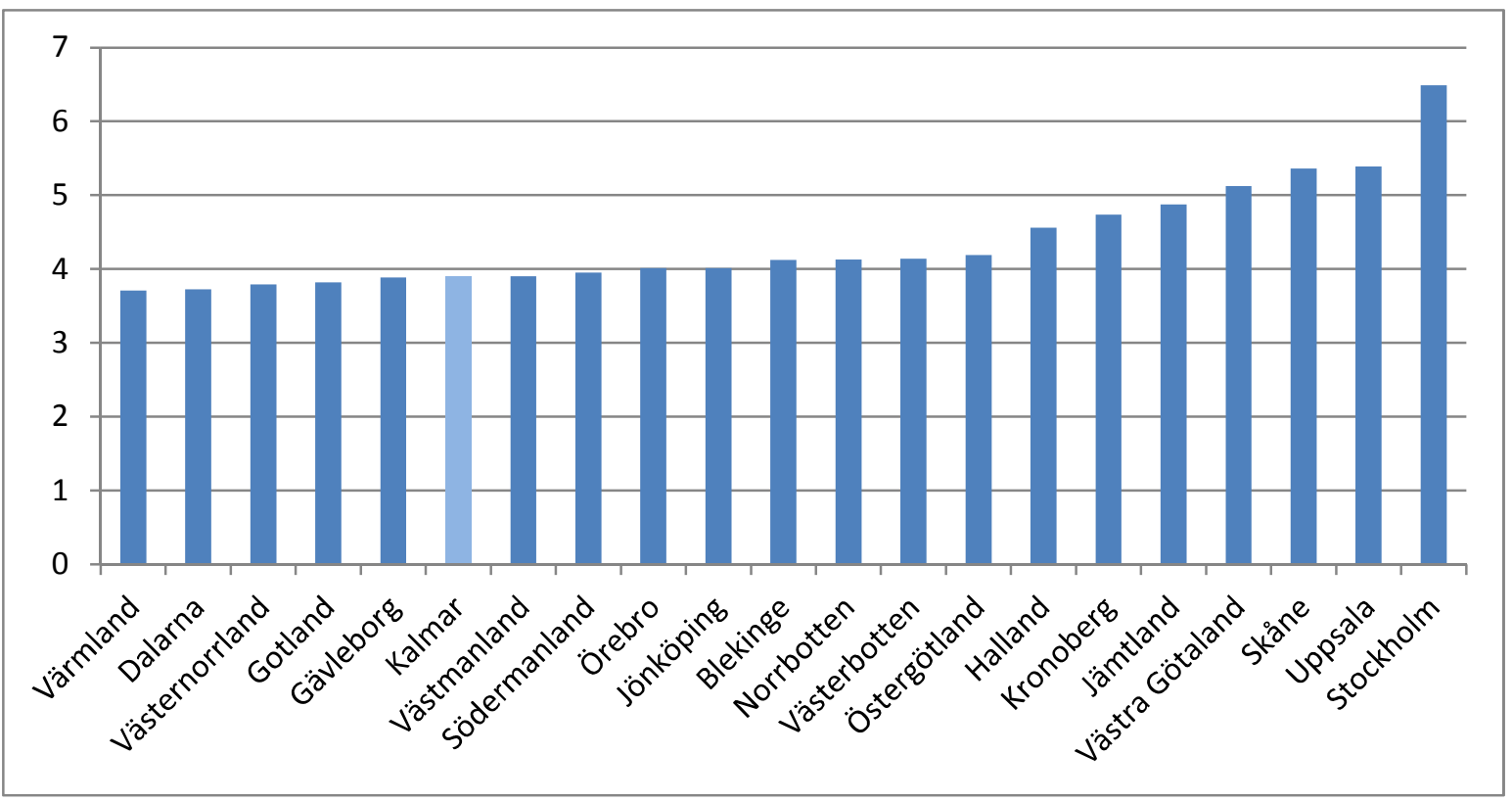

Source: Swedish Agency for Growth Policy Analysis (Tillväxtanalys)

There are also strong gender differences in the rate of start-up activity. As shown in Table 2.1, women are much less likely than men to pursue entrepreneurship activities. It should be noted that this trend is also evident throughout Sweden. 
Table 2.1 Share of start-ups in 2013 by county and sex

\begin{tabular}{|l|r|r|}
\hline & Women & Men \\
\hline Stockholms län & 36.0 & 64.0 \\
\hline Uppsala län & 33.9 & 66.1 \\
\hline Södermanlands län & 33.2 & 66.8 \\
\hline Östergötlands län & 31.2 & 68.8 \\
\hline Jönköpings län & 31.4 & 68.6 \\
\hline Kronobergs län & 32.0 & 68.0 \\
\hline Kalmar län & 33.0 & 67.0 \\
\hline Gotlands län & 34.5 & 65.5 \\
\hline Blekinge län & 29.3 & 70.7 \\
\hline Skåne län & 34.7 & 65.3 \\
\hline Hallands län & 34.5 & 65.5 \\
\hline Västra Götalands län & 33.5 & 66.5 \\
\hline Värmlands län & 33.5 & 66.5 \\
\hline Örebro län & 29.3 & 70.7 \\
\hline Västmanlands län & 31.8 & 68.2 \\
\hline Dalarnas län & 34.3 & 65.7 \\
\hline Gävleborgs län & 31.9 & 68.1 \\
\hline Västernorrlands län & 32.4 & 67.6 \\
\hline Jämtlands län & 32.9 & 67.1 \\
\hline Västerbottens län & 31.3 & 68.7 \\
\hline Norrbottens län & 32.1 & 67.9 \\
\hline Total & 34.0 & 66.0 \\
\hline
\end{tabular}

Looking at specific policies and programmes, there are collaborative innovation ecosystems in the bigger towns of the county, often in the form of triple-helix collaboration. The larger local governments (Kalmar, Oskarshamn and Västervik) play a role in the entrepreneurial/innovation ecosystems by participating in strategic partnerships and collaborating within a triple-helix model with the university, the industries and the government.

Knowledge-sharing activities on innovation and entrepreneurship between research institutions and industry is encouraged mainly through workshops. Linnaeus University plays an active role through its IEC and other activities. The programme for rural development (Landsbygdsprogrammet) is involved in knowledge-sharing activities. There is also a goal to support knowledge-sharing through the Äspö Hard Rock Laboratory, which conducts geological studies outside of Oskarshamn. 


\section{Box 2.6 Nova Oskarshamn}

Nova is an organisation for economic development created by the local government of Oskarshamn. It provides an ecosystem of innovation based on a triple helix model. The purpose is to establish collaboration in research and development, training and other services.

Nova works closely with two major organisations in the area, Scania and SKB. The first is a producer of world class trucks, part of which is made in Oskarshamn. The other one is a national company with a branch in Oskarshamn that handles radioactive waste from nuclear power plants. SKB funds research in geology and runs several labs and about 100 researchers from eight universities are active in the lab outside of Oskarshamn.

Nova provides education and training, as part of Yrkeshögskolan or by agreements with universities. It provides opportunities for networking between firms and the R\&D facilities. It also provides an incubator and other services to help firms develop.

Source: http://www.novaoskarshamn.se/

\section{Ensuring growth is inclusive}

Figure 2.7 Assessment results for ensuring growth is inclusive

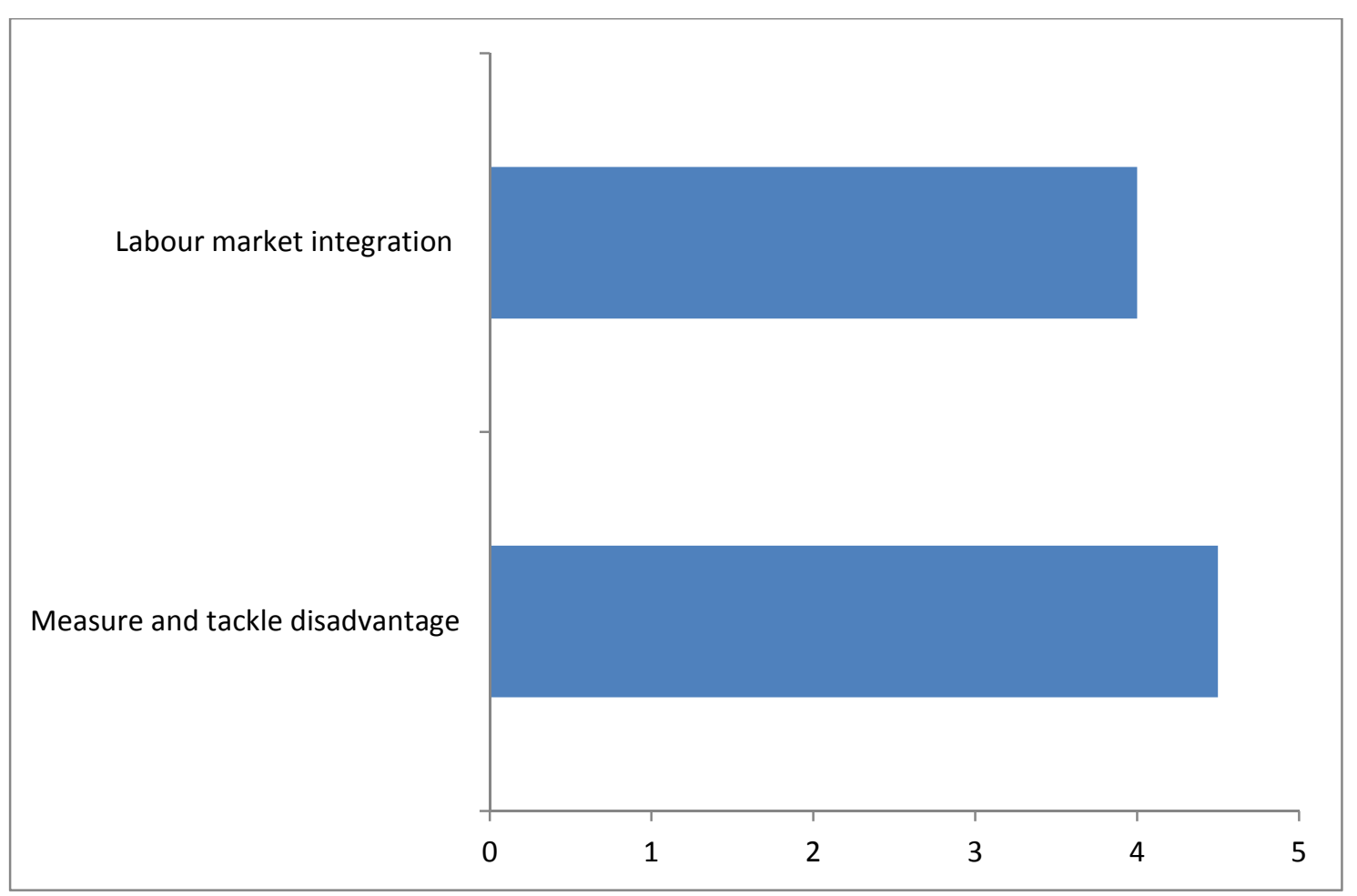

Extent to which effective policies are in place to support the labour market integration of disadvantaged groups and degree of flexibility in adapting programmes to different target groups

Many targeted programmes and projects for vulnerable groups, such as NEETs, exist in Kalmar county. A broad range of initiatives are addressed to at risk groups and their evaluation shows that they have contributed to reducing exclusion rates for these groups. There are many programmes by all levels of government which support individuals. 
One of the main priorities for the employment service is to help the long-term unemployed as well as people with disabilities. The public employment service also works with local partners to create jobs/job placements for people not ready to enter formal employment (e.g. the disabled or disadvantaged). Comprehensive efforts are made, through subsidised employment opportunities or agreements with employers, to create jobs/job placements for people not ready to enter formal employment.

There is a wide range of subsidies which can be given to employers to hire people who would otherwise not find jobs, for example due to mental disabilities. It is also promoted through social enterprise (socialt företagande). Another example is the public company Samhall which provides shielded work and has managed to establish itself as a brand name.

In recent years, a number of initiatives were targeted towards migrants who are seen as a possible resource to reduce skills shortages and enhance growth. Specific training programmes have been provided for local at risk groups that are assisted through the provision of child care and extra language training that is generally provided by local governments. One example is a project to support diversity in the care sector (Mio, Mångfald i omsorgen).

Special modular courses across a number of different sectors are available to help immigrants improve and adapt skills gained abroad. This is mainly done through training programmes offered by the employment service. In the region, language training is available at all skill levels and meets local demand. Additional language training is available to specific occupations; for example the program in Swedish for immigrants (SFI) is offered locally to specific groups, such as doctors, where the language requirement may be the only barrier for a job. This is also achieved through work-life practice (praktik).

\section{Box 2.7 Developing a local strategy for the integration of migrants}

Local activities to integrate migrants into Swedish society is coordinated by the County Administrative Board (Länsstyrelsen), which is a regional agency of the national government ("a prefecture"). The strategy is signed by 26 parties, including the regional and local governments, national agencies and private companies. It is based on a previous strategy from 2006 and relates to the general strategy for regional development (RUS), coordinated by the Regional Council in Kalmar County.

The strategy is based on the assumption that immigrants are a vital source of skilled labour in the region. The strategy states that collaboration is needed to ensure immigrants are treated like other Swedes in order to further increase the attractiveness of the region to immigrants. In order to achieve this target, more emphasis should be put on diversity in the broader regional development strategy.

The strategy has identified five areas of priority. One relates to jobs and skills development, while the others refer to language training, health, housing and social cohesion. The implementation of the strategy will be organised through a set of working groups with yearly follow-ups. The strategy also includes a list of activities to be carried out by each partner organisation, including the employment service and the local governments, which run a number of programs for immigrants.

Source: http://www.lansstyrelsen.se/kalmar/sv/manniska-och-samhalle/integration/integrationsstrategi-for-kalmarlan/Pages/default.aspx

\section{Extent to which there are evidence-based tools used to measure disadvantage on the labour market and support multi-stakeholder approaches to tackling disadvantage}

Policies have been implemented in the form of cross sector programmes/initiatives/adaptation of mainstream services to support NEETs ("not in education, employment or training") who are not 
registered as unemployed. There is a tradition of programmes for this target group. One of the more recent projects is the Plug-In, of which Kalmar county was one of the founders.

Some ad-hoc initiatives are in place to support school drop outs and to recognise skills and/or support young people to go back into education or into the labour market. One example is the program by the employment service to support non-traditional education (Folkhögskola).

\section{Box 2.8 Plug in 2.0}

Kalmar county was one of the founding participants in the project Plug-In, which aims to reduce the proportion of students who do not complete upper secondary school in four years from 24 percent to 12 percent. The project operates at a number of levels. The Swedish Association of Local Authorities and Regions (SALAR), which represents the governmental, professional and employer-related interests of Sweden's municipalities and county councils, plays the lead coordination role at the national level. SALAR's five participating regional councils translate the national objectives to the regional level, promote regional collaboration, and support the work of schools and municipalities. Finally, local, municipal, and/or school authorities are responsible for implementing the more than 100 initiatives and projects that comprise Plug In. The European Social Fund provides funding for the project, which is distributed across local municipalities.

Because of the decentralised nature of the project, there is no single Plug In model. Rather, regions, municipalities, and schools have taken various approaches. Some projects focus on improving processes and systems-for example, improving the transfer of information about at-risk students when they start upper secondary school and improving IT systems to track students across schools. Other projects focus more on support to students, such as enhanced outreach to students who have dropped out or are at risk of dropping out, individualised coaching and mentoring, and study support.

Kalmar county is now part of Plug In 2.0, which continues to develop individualised solutions. Key concepts are flexibility, collaboration, relationship and follow-up. Software is developed to provide guidance for civil servants on success factors and good examples in dealing with drop-outs. The ambition is to reach 3.000 young adults in six regions.

Source: $\underline{\text { http://www.rfkl.se/sv/Verksamheter/larande-kompetens/Projekt/Plug-In/Plug-In---dokumentation/ }}$ 


\section{Section 3}

\section{TOWARDS AN ACTION PLAN FOR KALMAR: RECOMMENDATIONS AND BEST}

PRACTICES

Stimulating job creation at the local level requires integrated action across employment, training, and economic development portfolios. Co-ordinated place-based policies can help workers find suitable jobs, while also contributing to demand by stimulating productivity. This requires flexible policy management frameworks, information, and integrated partnerships which leverage the efforts of local stakeholders. This section outlines the key recommendations emerging from the review of local job creation policies in Kalmar. 


\section{Co-ordination between employment, skills and economic development policies}

Recommendation: Transform regional partnerships into systems of learning which effectively promote evidence-based approaches to job creation, employment, and participation

Services for individuals and firms need to be delivered in a more coordinated manner. In particular, services to reach out to employers are provided by many organisations at different levels of government in Kalmar county. Resources can be used more effectively if there is a common understanding on how services relate to each other in order to avoid overlaps and duplication. Currently, there are strong informal networks; however there is no articulated and shared common vision for the county. Many stakeholders in Kalmar who attended the OECD workshop highlighted the potential benefits of strengthening existing collaboration (for example through the newly implemented skills platform), which could contribute to the development of strategic interventions in line with the different priorities of each municipality in the county

Partnerships need to develop a long-term vision if they are to work effectively and have a lasting effect. For area-based partnerships, this strategy must include a vision for the region focusing on the outcomes to be achieved, an action plan identifying short-term priorities, and coordinated work programmes including activities and measures that will contribute to the achievement of long-term outcomes. It is also necessary to develop a shared commitment to implement the programme and arrangements for monitoring and reporting progress.

Information and evidence play a critical role in bringing local stakeholders together. Often, this can be the 'glue' that enables local stakeholders to identify common issues facing their community. In order to build a strategic approach that is relevant to local conditions, it is essential to have a strong evidence base. Authoritative and updated skills profiles of local labour markets are important to frame providers' strategies and strengthen accountability and can also galvanise local actors into a common agenda for action when used well.

In Kalmar county, there is an opportunity to develop more formal partnerships, which act as learning systems and encourage local stakeholders to learn and think together about what works best locally. This would strengthen the capacity to analyse local data and create evidence based approaches to employment and skills. There were previously national attempts at forming learning systems at the regional level. Such learning systems could play an important role in building more effective services for clients, as well as establishing the most effective tools and methods for encouraging local employment and economic development. However, these systems would only work well if the regional actors have an impact on policy. 


\section{Box 3.1 OECD example: How to build successful partnerships?}

A locally-based partnership is usually designed to bring together all relevant actors within a region to address a specific issue within a community and/or improve its overall economic well-being. However, bringing together all relevant actors is not an easy task as this implies having not only different government institutions (usually of different levels), but also social partners, employers, NGOs, training institutions, and representatives of civil society around one table. Whatever the reason to set up a partnership, there are certain factors to bear in mind:

- Organisational structure: To be efficient, a partnership should have a recognisable and autonomous structure to help establish its identity. The structure should have stability and permanence as well as flexibility, and it is helpful if there is a certain independence from political influence. It is also important to review lines of communication to ensure that all partners are kept informed and involved. Equity should be a guiding principle in building a partnership, as should (for many partnerships) a "bottom-up" structure. Sufficient human and financial resources are also needed.

- $\quad$ Preparation: Preparatory work is crucial for developing a steady and effective partnership. Careful research into the context in which the partnership will be operating must be part of this phase. The strengths and weaknesses of the area should be assessed and effective measures designed. One of the most important aspects of this phase is to identify the right partners and establish clear roles for each.

- Work plan: Partnerships need to develop a long-term strategy if they are to work effectively and have a lasting effect. For area based partnerships, this strategy should include a vision for the region, focusing on the outcome to be achieved, an action plan identifying shorter-term priorities, and a co-ordinated working programme including activities and measures that will contribute to the achievement of long-term outcomes. The work programme should indicate the interests and targets of all partners and include activities and measures that will contribute to the improvement of the territory.

- Implementation: In this phase partners are in regular contact to co-ordinate implementation, to extend and supplement the working programme with new measures, and in some cases to test new approaches. Public relations activities should inform the wider public of the targets, activities and measures of the partnership.

- Monitoring: To assess a partnership's achievements, determine improvements to be made and adapt further planning, a comprehensive monitoring system should be used. A partnership should be evaluated periodically and publish reports to demonstrate the added value of its work.

Source: OECD (2014), Job Creation and Local Economic Development, OECD Publishing. DOI: 10.1787/9789264215009-en

\section{Creating productive economies}

Recommendation: Place a stronger emphasis on the quality of jobs and the better utilisation of skills to stimulate overall productivity within the local labour market

A key pillar of job quality is improving the utilisation of skills of those already at work. This requires not only considering how skills are provided by the education and training system, but the extent to which employers develop and utilise skills. OECD research has shown that local public agencies can contribute to improving how skills are put to use by using a number of different policy instruments, such as incentives for employers to invest in new technology and the promotion of more effective forms of work organisation (Froy and Giguère, 2010).

In Kalmar county, investment in the supply of skills alone will not be sufficient to secure job creation and productivity in all local economies. The degree to which local employers are demanding and using skills also has to be taken into account. Where the demand for skills among employers is low, and 
people's skills are not fully utilised, this can undermine productivity. It can also reduce the quality of local jobs in terms of salaries, job security and the possibility for career progression.

\section{Box 3.2 OECD example: Mechanisms which can boost the utilisation of skills}

\section{Guidance, facilitation and training}

- Support technology transfer: facilitating investment in new technology by employers, setting up partnershipsfor the sharing of innovation and new technologies.

- Provide technical assistance to improve working conditions and work organisation: this may mean the re- professionalisation of front-line positions in some sectors and a reduction in dependence on temporary staff, while in others it may mean applying lean manufacturing techniques. Providing staff with enough time to pass on skills and learning is also important.

- Encourage participation in training for both managers and workers: better trained managers are likely to create more productive working environments for their staff. At the same time, companies need to be encouraged to make training and other skills development opportunities available to their employees.

\section{Finance and procurement}

- Ensure the availability of patient capital: in order to invest fully in their staff and upgrade their production processes, companies need long-term investment security. The availability of local "patient capital" (i.e. funds invested for medium or long term, generally for 5 to 10 years) will be important for this.

- Develop a quality-driven supply chain: public procurement can also be used to help local firms think longer term and therefore invest in increased productivity. This can include, for example, longer contracting periods. In addition government contracts can require a certain level of working conditions, and a certain level of commitment to training.

- Support social enterprise: given that social enterprises can avoid some of the short-term pressures associated with satisfying private shareholders, they can in some cases take a longer-term perspective to developing and training their staff.

\section{Influencing broader public policies}

- Remove local disincentives to a focus on quality in the public sector: this may include changing incentive structures for local employment agencies so that they concentrate on the quality and not just the quantity of job- matches.

- Ensure that skills policies are embedded in economic development policies: local partnerships are needed between business and policy makers in the sphere of economic development, education and employment, in order to ensure that skills policies are understood in the context of broader economic development.

\section{Work in partnership}

- Work with intermediaries: brokers and intermediary bodies can be particularly useful when working with employers on productivity issues, particularly as this is not a traditional domain for public policy.

- Work with unions: unions are natural partners in improving the quality of employment at the local level. Not only are unions increasingly involved in co-ordinating training for their members, but they also have an interest to see that work organisation and employment conditions improve for skilled staff. They are a useful intermediary between the public sector and business.

Source: Froy, F. and S. Giguère (2010), "Putting in Place Jobs that Last: A Guide to Rebuilding Quality Employment at Local Level", OECD Local Economic and Employment Development (LEED) Working Papers, No. 2010/13, OECD Publishing, Paris. DOI: http://dx.doi.org/10.1787/5km7jf7qtk9p-en 
Recommendation: Increase the engagement of employers (especially SMEs) with the employment and skills system through greater outreach efforts and examine how to apply "career pathway" approaches in the region

Available data shows that Swedish employers spend relatively large amounts on skills development and training for the employed. Nevertheless, it is common for employers' organisations to express dissatisfaction with the lack of skills in many traditional sectors. This is phrased in more general terms as a question about the relevance of post-secondary education. Employers have a critical role to play in ensuring that the supply of skills meets demand. Therefore, it is important that the employment and training systems develop clear, coherent, and efficient engagement strategies to receive employer input on the relevance of skills being produced by the system.

While employers are involved in the development of Higher Vocational Education programmes (i.e. Yrkeshögskolan), there is a need to ensure they are fully engaged within other educational pathways. Kalmar county could look to other OECD countries, such as Canada and the United States, where employers are actively involved in an advisory capacity with the training system. In the United States, community colleges can rapidly develop courses because they use industry representatives as trainers. Because these trainers are from industry, it also helps to ensure a good relationship with employers. In some cases, community colleges have created a separate branch of their institution from the part of the college which offers more traditional academic courses, in order to be agile to local needs.

A new "career pathways approach" has been developed in the United States in recent years and Kalmar county could look to replicate these models to address some of its labour market barriers. Under this approach, customised training courses are linked together to form "career pathways initiatives" for low-paid workers, often jointly funded by the private and public sectors. The main components of the career ladder approach include defining appropriate training with industrial consortia and vocational education institutions; adapting training to the needs of working adults; linking training to career transitions, from entry-level to higher-level workers; and disseminating information through adultorientated careers advice (see Box 3.3).

\section{Box 3.3 OECD Example: Career cluster approaches in Maryland, United States}

In the United States, local and regional government agencies have increasingly adopted sectoral strategy approaches to economic development and a similar approach is surfacing in the workforce-development field. As partnership between workforce and economic development agencies becomes more common in regions and communities, the role of education and workforce agencies in mapping and building skills pipelines for key industries becomes more critical to economic-development practitioners.

Public education and workforce systems organise their work through pathways and cluster models. For high schools and community colleges, establishing career-pathway models helps to connect them to the economy, and to produce workers with the appropriate skills for jobs in the region.

Maryland started working on a sectoral strategy approach in 1995 under the School-to-Work Opportunities Act. Some 350 business executives in ten different sectors were brought together to inform education policy makers about their bottom line: how they made money and what they needed to be successful. The original project was funded with USD 25 million of federal School-to-Work funds, and the approach was bottom-up: mapping what knowledge and skills were required and developing programmes around clusters of skills. Within each county, a Cluster Advisory Board $(C A B)$ focused on different industry clusters. In Montgomery County, Maryland, for example, which hosts the third largest biotechnology cluster in the United States, a CAB is focused on the biosciences, health science and medicine cluster. Administrators, counsellors, and faculty members use the career-cluster system to develop programmes that extend from high school to two- and four-year colleges/universities, graduate schools, apprenticeship programmes and the workplace. Although the cluster framework was originally developed for high schools and young people, it is now being adopted by workforce investment boards and other programmes serving adults across the United States.

Source: OECD (2014e), Employment and Skills Strategies in the United States, OECD Reviews on Local Job Creation, OECD Publishing. DOI: $\underline{10.1787 / 9789264209398-e n}$ 


\section{Supporting entrepreneurship and economic development}

Recommendation: Improve job quality in targeted sectors, such as tourism by shifting from medium and low technology industry to more knowledge- intensive production

Kalmar county is classified as a low-skills equilibrium economy, which means that there is a prevalence of poor quality jobs in the regions relative to other regions in Sweden. While the public sector looks for more qualified staff, employers in the private sector in Kalmar mainly seek employees with low skills levels and this will have an impact on the labour market and the productivity of the region. To remain competitive, the industrial base of Kalmar county needs to shift from medium and low technology to more knowledge-intensive production. This will happen only if existing firms upgrade their production or if new firms will implement more advanced production.

Another issue relates to the relatively low access to finance by SMEs. It is of great importance that capital is available for SMEs to invest and grow. It is desirable that such capital is provided with competence in management and other skills needed in growing firms. Targeted efforts for various sectors can be expanded. The support for agriculture could be expanded into support for the tourism sector. Local services as well as focused investments in great attractions are needed. The region is successful in developing major attractions (Öland, Glasriket, Astrid Lindgrens värld). These can be further developed and serve as internationalised hubs.

Previous OECD research has discussed the importance of adopting a tourism value chain approach which takes into account the different skill levels in the sector and looks beyond specific occupations and branches to strengthen mobility and build the capacity of destinations to deliver quality tourism services (Stacey, 2015). This means looking at new ways of organising and managing human resources to support this, along with strategies to encourage more effective recruitment and retention and promote up-skilling, lifelong learning and opportunities for advancement. For inspiration, Kalmar could look to Blackpool, United Kingdom, which focused on enhancing the quality of its tourism offer as part of a job quality and employment strategy (see Box 3.3).

\section{Box 3.3 OECD Example: Creating a new type of tourism in Blackpool, UK}

Tourism was also central to the local economy in Blackpool, in the United Kingdom. Here it was again recognised that the local economy would benefit by raising the game in terms of the tourism offer. Having long been a seaside resort that caters for high volume but low-spending customers, Blackpool is working hard to raise its game and attract higher spending customers through offering a higher quality 'offer'. The town has been growing its branded attractions (e.g. Madame Tussauds, Nikolodean, Merlin) while also investing significantly in infrastructure (trams, cycles, buying the Blackpool tower for the public, new concert hall, refurbished front). It was recognised that capital and infrastructure investments alone will be insufficient to realising the town's vision, and that alongside them there is a need for investment in skills, particularly in the area of customer service. This means investment in specific skills (for example through local college courses geared to the tourism industry) but also more informal learning and knowledge sharing.

A particular emphasis has been placed on informal skills development to raise the aspirations of service personnel so that they project a better image of the town and at the same time become more committed both to Blackpool, their employers and their own personal career prospects. A good example of such an initiative is the Welcome to Blackpool initiative funded initially by the Local Enterprise Growth Initiative (LEGI) introduced by the previous UK government.

This project trains local people (especially those working in hospitality, leisure, tourism, transport and retail sectors, but also local residents) in appreciating the history of Blackpool, current developments and future plans. Through course attendance participants learn more about Blackpool's attractions and services. The knowledge gained can then be used to enhance visitor and local residents' experience of Blackpool. Employers have reported that the short course equips staff to deliver a high standard of customer service, which in turn impresses visitors to the town and encourages word of mouth recommendations and repeat visits to Blackpool. The initiative has shown that taxi 
drivers, those involved in tourism, and local residents can be excellent ambassadors for Blackpool It was reported that over 3,000 people (of all ages) have attended the course in two years and that more than 250 organisations have benefited. Such initiatives have been useful in increasing staff retention in local firms, which traditionally have had high turnover rates, linked to the seasonality of tourism in the town.

Source: Froy, F., S. Giguère and M. Meghnagi (2012), "Skills for Competitiveness: A Synthesis Report", OECD Local Economic and Employment Development (LEED) Working Papers, No. 2012/09, OECD Publishing, Paris. DOI: http://dx.doi.org/10.1787/5k98xwskmvr6-en

\section{Ensure growth is inclusive}

Recommendation: Increase the labour market participation rate, especially among vulnerable groups, such as immigrants, and women. This could be done through strong entrepreneurship opportunities which provide skills and mentorship opportunities.

Kalmar county will need to focus efforts on improving the overall labour force participation rate for women and immigrants to boost the available labour supply in the local economy. Women in the county currently face a bipolar labour market with a mix of high and low skilled jobs. This report has showed that men are more likely to be either in professional and scientific or physical jobs in the county These gender differences should be a source of policy action in the county. Targeted programmes and policies should be introduced to promote women's participation, particularly for those who are low-skilled.

To address the skills shortages, immigrants have been identified as a potential source of higher skills. However, Kalmar county needs to look at further actions to speed up the integration of migrants in the labour market through a quicker assessment of their skills. There is no question that formal requirements such as language training need to be targeted to these groups as soon as possible to help speed up their labour market integration.

Entrepreneurship has a crucial role to play in modern societies due to its contribution to the generation of new ideas, innovation, job creation and economic growth. It has the potential to create jobs and reduce unemployment, not just in the population in general, but also among people who are vulnerable to social exclusion (OECD, 2014). There are several initiatives both nationally and locally to support entrepreneurship. To boost overall job creation in the region, one option would be to investigate the possibility of strengthening SME inter-nationalisation support, especially with a focus on connecting some of the larger enterprises in the region with local SMEs. It is recommended that the county further explore how best to encourage entrepreneurship opportunities for women. Equally important, migrants could also enter the labour market as entrepreneurs. Their values and previous experiences can be a source of inspiration for creating new businesses. It is important that barriers for start-ups created by migrants and other disadvantaged groups are lowered.

To successfully start up and operate a business, entrepreneurs need to use a wide range of skills. This skill-set includes skills that are required from employees in any workplace, but also those skills needed to respond to the additional demands of running a business (OECD/European Commission, 2013). While some of these skills may not be absolutely necessary for successfully operating a business, possessing them is likely to increase the quality of an entrepreneur's business and the chances that it will be sustainable and grow. It is therefore important to identify the skills needed by entrepreneurs and consider how they may be acquired and strengthened, and how this can be supported by public policy. 


\section{References}

Bussi, M. and J. K. Pareliussen (2015), "Skills and labour market performance in Sweden", OECD Economics Department Working Papers, No. 1233, OECD Publishing, Paris.

DOI: http://dx.doi.org/10.1787/5js0cqvnzx9v-en

Froy, F., S. Giguère and A. Hofer(eds.) (2009), Designing Local Skills Strategies, Local Economic and Employment Development (LEED), OECD Publishing, Paris.

DOI: http://dx.doi.org/10.1787/9789264066649-en

Froy, F. and S. Giguère (2010), "Putting in Place Jobs that Last: A Guide to Rebuilding Quality Employment at Local Level", OECD Local Economic and Employment Development (LEED) Working Papers, No. 2010/13, OECD Publishing, Paris. DOI: http://dx.doi.org/10.1787/5km7jf7qtk9p-en

Froy, F., S. Giguère and M. Meghnagi (2012), "Skills for Competitiveness: A Synthesis Report",OECD Local Economic and Employment Development (LEED) Working Papers, No. 2012/09, OECD Publishing, Paris.DOI: http://dx.doi.org/10.1787/5k98xwskmvr6-en

OECD (2015a), OECD Economic Surveys: Sweden 2015, OECD Publishing, Paris. DOI: http://dx.doi.org/10.1787/eco_surveys-swe-2015-en

OECD (2015b), OECD Employment Outlook 2015, OECD Publishing, Paris.DOI: http://dx.doi.org/10.1787/empl outlook-2015-en

OECD (2015c), "Sweden", in OECD, Financing SMEs and Entrepreneurs 2015: An OECD Scoreboard, OECD Publishing, Paris. DOI: http://dx.doi.org/10.1787/fin sme ent-2015-35-en

OECD (2015d), Employment and Skills Strategies in Sweden, OECD Reviews on Local Job Creation, OECD Publishing, Paris. DOI : http://dx.doi.org/10.1787/9789264228641-en

OECD/ (2014a), Matching Economic Migration with Labour Market Needs, OECD Publishing, Paris. DOI: http://dx.doi.org/10.1787/9789264216501-en

OECD (2014b), OECD Employment Outlook 2014, OECD Publishing, Paris.

DOI: http://dx.doi.org/10.1787/empl_outlook-2014-en

OECD (2014c), Job Creation and Local Economic Development, OECD Publishing. DOI: $10.1787 / 9789264215009$-en

OECD (2014d), Employment and Skills Strategies in Canada, OECD Reviews on Local Job Creation, OECD Publishing. DOI: 10.1787/9789264209374-en;

OECD (2014e), Employment and Skills Strategies in the United States, OECD Reviews on Local Job Creation, OECD Publishing. DOI: 10.1787/9789264209398-en

OECD (2013a) Policy Brief on Youth Entrepreneurship, OECD Publishing, http://www.oecd.org/cfe/leed/Youth\%20entrepreneurship\%20policy\%20brief\%20EN_FINAL.pdf 
OECD (2012a), the OECD Skills Strategy: Better Skills, Better Jobs, Better Lives: A Strategic Approach to Skills Policies. OECD Publishing, Paris, DOI: http://dx.doi.org/10.1787/9789264177338-en

OECD (2012b), OECD Territorial Reviews: Småland-Blekinge, Sweden 2012, OECD Publishing, Paris. DOI : http://dx.doi.org/10.1787/9789264169517-en

Stacey, J. (2015), "Supporting Quality Jobs in Tourism", OECD Tourism Papers, No. 2015/02, OECD Publishing, Paris. DOI: http://dx.doi.org/10.1787/5js4rv0g7szr-en 